See discussions, stats, and author profiles for this publication at: https://www.researchgate.net/publication/271899048

\title{
Stone Axe Studies in Ireland
}

Article · January 2014

DOI: $10.1017 / 50079497 \times 00004242$

\section{CITATIONS}

11

3 authors:

Alison Sheridan

National Museums Scotland

124 PUBLICATIONS 1,411 CITATIONS

SEE PROFILE

Eoin Grogan

National University of Ireland, Maynooth

6 PUBLICATIONS 56 CITATIONS

SEE PROFILE

Some of the authors of this publication are also working on these related projects:

North Roes Felsite Project View project

Scottish archaeology View project
Gabriel Cooney

University College Dublin

44 PUBLICATIONS 294 CITATIONS

SEE PROFILE 
Proceedings of the Prehistoric Society 58, I992, pp. 389-416

\title{
Stone Axe Studies in Ireland
}

\author{
By Alison Sheridan ${ }^{1}$, Gabriel CoOney ${ }^{2}$ and Eoin Grogan ${ }^{3}$
}

This paper starts by outlining the history of stone axe studies in Ireland, from their antiquarian beginnings to 1990 . It then offers a critical review of the current state of knowledge concerning the numbers, distribution, findspot contexts, morphology, size, associated finds, dating and raw materials of stone axes. Having proposed an agenda for future research, the paper ends by introducing the Irish Stone Axe Project - the major programme of database creation and petrological identification, funded by the National Heritage Council, currently being undertaken by GC and EG.

"AG 425 . Stone axe, $87 / 16^{\prime} \times 3 \% 8^{5}$, found by "Richard Glennon and James Nolan of the Batchelor's Walk, Dublin, stuck in the frontal bone of a female giant deer of Ireland, at a place called Lough Gur, ten miles from Limerick on the Cork road - the broad end in the shaft." (Entry in National Museums of Scotland catalogue relating to acquisition of an Irish axe in I920)

The last two decades have witnessed a flurry of stone axe studies in Britain, with publication of the results of half a century's work by the Council for British Archaeology Implement Petrology Committee (CBA IPC) and its precursor (Clough \& Cummins ( $1979 ; 1988)$, excavation and survey of axe production sites at Great Langdale (Bradley \& Edmonds 1988; Claris \& Quartermaine 1989) and Creag na Caillich (Edmonds et al. in press), and publication of several papers discussing the distribution of axes and the mechanisms producing the observed patterns (e.g. Cummins 1974; 1978; 1979; 1980; Darvill 1989; Elliott et al. 1978; Hodder \& Lane 1982).

In Ireland, by contrast, stone axe studies over this period have been handicapped by the absence of a systematic, large scale petrological survey and the lack of research-based excavations at production sites. Nevertheless, as recent publications by Cooney ( 1985 ; 1989; Cooney et al. 1990), Francis et al. (1988), Grogan \& Cooney (1990) and Sheridan (I986a) make

\footnotetext{
${ }^{1}$ Royal Museum of Scotland, Queen Street, Edinburgh EH2 I JD

2 Department of Archaeology, University College Dublin, Belfield, Dublin 4

${ }^{3}$ North Munster Research Project, Discovery Programme, Dublin
}

clear, the study of stone axes in Ireland has been far from dormant.

The term 'stone axe' will be used throughout, except where specified otherwise, as a shorthand term to cover axeheads, adzes and chisels, and to encompass specimens of all rock types including flint. Note also the use of 'NMI' for the National Museum of Ireland and 'UM' for the Ulster Museum.

\section{HISTORY OF IRISH STONE AXE STUDIES}

The individual who can be credited with initiating serious research into stone axes in Ireland is William J. Knowles, a prodigious collector of antiquities based at Ballymena, Co. Antrim, who published accounts of several so-called 'axe factory' sites at and around Tievebulliagh in 1903 and 1906 , as well as several other articles concerning Irish axes (e.g. I 893; I9 I3). Having located these manufacturing sites, Knowles focused his researches on identifying the stages involved in the production of porcellanite axes, and whilst he failed to realize that this type of rock actually outcropped on Tievebulliagh, his work laid the foundations for all subsequent studies of porcellanite axes.

Earlier Irish antiquaries had shown an interest in stone axes, often amassing important collections (e.g. Wilde 1857 ). However, as the unpublished midnineteenth-century notebooks of John Bell of Dungannon make clear, the prevailing view regarding the function of these artefacts amongst 19 th century antiquaries 
was that they were weapons, used either as tomahawks or as 'champion hand stones':

'The large flint hatchets are formed in the same dexterous manner as the smallest and most delicately fashioned arrowheads,... [and] there seems from these premises some reason to believe they ... were used as weapons - and if this is the case, to suppose the polished celts made of basalt, granite and other mateals (sic) were used for other than warlike purposes would to me seem not so probable. Celts although they may seem well adapted for the purposes of skinning animals yet I have neither heard or read that they have at any time been employed for that purpose.' (Farmer Collection MSS no. 332, University of Glasgow Library, p. 52.)

Wilde, however, admitted the possibility that axes could also be used for tree-felling, woodwork and mining ( $1857,49-50)$, and Knowles suggested that only the larger specimens might have been used for warfare, the smaller ones acting as the stock-in-trade of the Stone Age carpenter (I 893 , I60; cf. O'Laverty I 857, I 24).

Bell added that 'the common people' of Ireland and Scotland generally believed stone axes to be 'Jove's thunderbolts', and observed that the Ulster linen weavers were re-using axes as linen smoothers (Farmer Collection MSS no. 332, University of Glasgow Library, p. 52; cf. J. Evans I 897, 56).

Whilst the collecting of Irish stone axes by individuals and museums has continued to the present, the history of Irish stone axe studies in the post-Knowles era has been one of sporadic activity, much of it up to the I 950 S being undertaken from outside Ireland. The establishment of the Sub-Committee of the South-Western Group of Museums and Art Galleries on the Petrological Identification of Axes (SWGSC) in 1936, under the chairmanship of Alexander Keiller, marked the beginning of the systematic petrological survey of stone axes in Great Britain, and in its first Report (Keiller et al. I 94 I), the Committee formally labelled porcellanite as Group IX rock. Three Group IX axes from England are listed, together with two roughouts from Cushendall, Co. Antrim, and the authors added that several hundred more porcellanite axes were to be found in the NMI and the (then-named) Belfast Museum (i.e. UM: Keiller et al. I94 I, 64). Subsequent SWGSC (and, from I952, CBA IPC) Reports list further Group IX specimens in Britain, and also a few non-porcellanite axes of suspected Irish origin from British findspots (Stone \& Wallis I 947, 52, 54; but cf. Stone \& Wallis I95 r, roo and Jope I952, 47).

Although the SWGSC primarily focused its attention on axes from British findspots, nevertheless Keiller's strong interest in Irish axes ensured that material from Irish findspots was not altogether omitted from the survey. Keiller's own study of part of the Knowles collection in 1926 had led to his discovery of two imported axes of Group XIII Preseli dolerite from Co. Antrim (Keiller 1936; see also Clough \& Cummins I988, 260), and in the SWGSC's First Report, reference is made to the geological investigation of Tievebulliagh (following the discovery of the porcellanite outcrop in the r 930 s by Estyn Evans), undertaken by Ashby and Tomkeieff on behalf of the Committee (Tomkeieff I940). Subsequent SWGSC/CBA IPC Reports also include a handful of petrological identifications for axes from Irish findspots, including those held in British museums (e.g. Stone \& Wallis I95 I, no. 86; see also Evens et al. I 962, no. 86) and a few in Irish collections (e.g. Stone \& Wallis I95I, no. 363). The total number of such identifications is given as $\mathrm{I} 2$ in Clough \& Cummins's r988 publication (p. 260).

Other British interest in Irish axes has tended to take two main forms: firstly, the study of jadeite specimens, in which Ireland is treated as part of a broader study of import patterns (e.g. Bishop et al. 1977; Smith I963; Woolley etal. I979); and secondly, the study of porcellanite axe exports to Scotland (Clarke 1968; Livens I959; McVicar 1982; Ritchie 1968; Ritchie \& Scott I988; Scott 1969; I973). There have also been attempts to distinguish between the Tievebulliagh porcellanite and that from the second source (see below) at Brockley on Rathlin Island. Vin Davis's preliminary petrological work concluded that this could not be done using standard optical microscopy, whilst the results of Warrington Cameron's mineralogical and chemical work remain unpublished (Davis pers. comm.).

In Ireland, meanwhile, the first attempt at a systematic petrological examination of stone axes was Martin Jope's work on porcellanite, undertaken in collaboration with several archaeologists and geologists including June Morey and Peter Sabine of the Geological Survey (South Kensington) and Jack Preston of the Geology Department, Queen's University of Belfast (Jope I952; Morey \& Sabine I952). Preston also made microscopic and thin-section examinations of nonporcellanite axes and other implements at the time and for thirty years afterwards, and the preliminary results of his work on 462 specimens were published recently (Francis et al. I988).

Although the primary aim of Jope's work was a preliminary survey of the distribution of porcellanite 


\section{J. A. Sheridan et al. STONE AXE STUdies IN IRELAND}

axes, it also investigated their date, morphology, use, manufacturing process, organization of production and 'factory sites'. Fresh archaeological and geological information about Tievebulliagh was presented, and the second source at Brockley on Rathlin Island, Co. Antrim, was also discussed. Although the existence of at least one manufacturing site on Rathlin had been known for over half a century (Gray I882; Knowles I906), the outcrop was not noted in print until I934 (Whelan I934); its geological characteristics were described briefly by Thomas (in Whelan 1934) and by Dawson (I95I).

Subsequent work on porcellanite has consisted of the aforementioned characterization studies by Davis and Warrington Cameron; a small-scale rescue excavation and palaeoenvironmental survey at Tievebulliagh by Mallory (Mallory I985; I990); a new survey of the distribution, date and characteristics of porcellanite implements by Sheridan (1986a); and a critical review of the evidence relating to axe manufacture and dispersal by Briggs (1988). One other piece of relevant work - albeit not initiated in Ireland and not inspired by axe studies - is Agrell and Langley's geological study of the dolerite plug at Tievebulliagh (1958). This provided valuable information on the mineralogy of the Tievebulliagh and Brockley porcellanites.

Other Irish-based work since Knowles has reflected a continuing interest in several aspects of stone axes. Regarding petrology, the work of J. J. Hartley, Frank Mitchell and J. S. Jackson should be mentioned alongside that of Preston. Jackson, for example, was responsible for the identifications given in the NMI's Acquisition Lists for I957-I970 (e.g. J. Raftery 1968), and he noted possible sources, as in the case of the porphyritic andesite axes found at Feltrim Hill, Co. Dublin, which he suspected to have come from Portrane and/or Lambay Island (Hartnett \& Eogan 1964). Axes of this material are known from Lambay Island itself. A valuable contribution to the question of axe sourcing has also been made by Briggs (e.g. 1988), who has pointed out the need for more studies of erratic rock distribution.

The find contexts of Irish axes have been discussed by several scholars, such as Knowles (1913), Armstrong (I9I 8), Mahr (I937) and J. Raftery (I95I). Armstrong dealt with associated finds, whilst the others remarked upon the frequency of river finds, and developed with such observations the concept of specific riverine cultures (i.e. Mahr's 'Riverford Civilization' and J. Raftery's 'Bann Culture’).
As for chronology, few studies have specifically addressed the issue of the timespan of stone axe use, although Knowles voiced his suspicion of a Neolithic date for porcellanite axes as early as 1903, and a pre-Neolithic date for some flaked flint axes in 1893 . Others have since extended the time range for axe use in general back to the Early Mesolithic and forward to the Middle Bronze Age, if not later (see below; Pollock \& Waterman 1964; Ryan I980; Woodman I977a; I978; I985).

In the recent past, detailed work on the number, context, distribution, size and morphology of axes in north Leinster and Munster has been carried out by Cooney (1985; 1987; 1989; Cooney et al. 1990) and Grogan (1989; see also Grogan \& Eogan 1987) as part of their analyses of prehistoric settlement in these two regions. Other recent work includes Briggs's study of stone axe distribution patterns in central Ulster and their relationship to prehistoric settlement evidence (1985), and Woodman's investigations into raw material exploitation, notably of mudstone ( 1987 ; Woodman \& Johnson in press) and flint (Woodman I992; Woodman \& Griffiths I988).

\section{THE CURRENT STATE OF KNOWLEDGE}

\section{Numbers and distribution}

Grogan and Cooney's preliminary survey of the stone axes held by the principal Irish museums (1990) revealed that around I0,600 specimens are known (including c. 2500 porcellanite roughouts in the UM, collected by Knowles at Tievebulliagh and Glen Ballyemon), of which roughly $50 \%$ have findspots indentifiable to at least townland level. The latter's distribution is shown in fig. $I$. (The map excludes those axes found in rivers whose findspots can be identified to townland level, for the sake of avoiding bias against other riverine finds from less specific locations.) The Io,600 total includes numerous adzes, chisels etc. as well as axeheads sensu stricto, but quantification of the relative proportions of each implement type awaits further, systematic study.

From fig. I and table $I$ it is clear that a major proportion of specimens derive from the North-East, primarily Counties Antrim and Derry. Whilst it is known that a considerable amount of prehistoric activity took place in this part of Ireland, this distribution map cannot be taken as an accurate indicator of the extent and density of Mesolithic, Neolithic and Bronze Age settlement. 
TABLE I: PRELIMINARY (PRE-IRISH STONE AXE PROJECT) SURVEY OF IRISH STONE AXES BY FINDSPOT LOCALITY

\begin{tabular}{|c|c|c|}
\hline & Townland & County \\
\hline \multicolumn{3}{|l|}{ ULSTER } \\
\hline Antrim & I96I & 828 \\
\hline Armagh & 38 & 30 \\
\hline Cavan & 81 & 5 \\
\hline Derry & 439 & 30 \\
\hline Donegal & 105 & 4 \\
\hline Down & 275 & 28 \\
\hline Fermanagh & 45 & 33 \\
\hline Monaghan & 25 & I7 \\
\hline Tyrone & 56 & 22 \\
\hline \multicolumn{3}{|l|}{ LEINSTER } \\
\hline Carlow & 17 & - \\
\hline Dublin & 59 & - \\
\hline Kildare & I IO & 7 \\
\hline Kilkenny & 8 & I \\
\hline Laois & $2 I$ & 2 \\
\hline Longford & 39 & 3 \\
\hline Louth & 26 & 3 \\
\hline Meath & 128 & 22 \\
\hline Westmeath & 83 & 22 \\
\hline Wexford & I 2 & 2 \\
\hline Wicklow & $3 I$ & 4 \\
\hline \multicolumn{3}{|l|}{ MUNSTER } \\
\hline Clare, including Shannon $\mathrm{R}$. & 874 & I \\
\hline Cork & $3 I$ & I \\
\hline Kerry & 24 & I \\
\hline Limerick & $35^{8}$ & 4 \\
\hline Tipperary & 33 & I \\
\hline Waterford & 8 & $x$ \\
\hline \multicolumn{3}{|l|}{ CONNAUGHT } \\
\hline Galway & 222 & I I \\
\hline Leitrim & 15 & I \\
\hline Mayo & 68 & 6 \\
\hline Roscommon & 58 & \\
\hline Sligo & 62 & 6 \\
\hline \multicolumn{3}{|l|}{$\begin{array}{l}\text { POORLY-PROVENANCED SPECIMENS } \\
\text { Ulster Museum }\end{array}$} \\
\hline North of Ireland/North & \multicolumn{2}{|c|}{1382} \\
\hline $\begin{array}{l}\text { East of Ireland/Ireland } \\
\text { Bann unlocalised fothers under Antrim }\end{array}$ & \multirow{2}{*}{\multicolumn{2}{|c|}{$8 I$}} \\
\hline $\begin{array}{l}\text { Bann uniocalised [otners under Antrim } \\
\text { and Derry] }\end{array}$ & & \\
\hline $\begin{array}{l}\text { Knowles collection of porcellanite } \\
\text { roughouts }\end{array}$ & \multicolumn{2}{|c|}{ c. 2500} \\
\hline \multicolumn{3}{|l|}{ Monaghan County Museum } \\
\hline No location & & 6 \\
\hline \multicolumn{3}{|l|}{ National Museum of Ireland } \\
\hline Ireland & \multicolumn{2}{|c|}{165} \\
\hline North of Ireland & \multicolumn{2}{|c|}{ ro } \\
\hline East of Ireland & \multicolumn{2}{|r|}{ I } \\
\hline South of Ireland & \multicolumn{2}{|r|}{$\mathbf{I}$} \\
\hline Lough Gara & \multicolumn{2}{|r|}{60} \\
\hline
\end{tabular}

Townland $=$ provenanced to townland level: County $=$ provenanced to County level only
Major contributory factors to this bias are (a) the concentration in the North-East of I9th- and 2othcentury antiquities collectors (see Woodman 1978) and (b) the presence of the two porcellanite sources in Co. Antrim, whose products account for some $70 \%$ of the Counties Antrim and Derry specimens shown on the map. Indeed, the bias would be yet more marked were the map to include the hundreds of stone axes from the Bann River; Knowles (1913) recorded nearly a thousand of these in his collection.

There are several other areas of relatively high density (see fig. I), including the Lough Gur area, Co. Limerick (Grogan \& Eogan 1987), the head of Galway Bay, and the area around Killaloe, Co. Clare. Excluded from the map, but included in table $\mathrm{I}$ under 'Clare', are the 708 axes dredged from the Shannon around Killaloe which ended up in the NMI; Mahr (1937) refers to the discovery of over 900 from this area, although clearly his figure includes other artefact types such as 'salmon clubs'. Smaller concentrations are to be seen, for example, in the Loughcrew-Boyne Valley area of north Leinster (Cooney 1989), on the Kildare side of the River Barrow, and immediately south of the Burren in Co. Clare. Once more, a significant contributory factor to this pattern is the activity of Igth- and 2oth-century collectors.

\section{Findspot contexts}

The vast majority of stone axes fall into the amorphous category of so-called 'stray' finds, with rivers producing a substantial number (see below) and excavations providing a small but growing number. Accurate percentages for the various types of findspot context are not yet available for the whole of Ireland, but the pattern for north Leinster is shown in fig. 2. Cooney's attempt to relate axe distribution patterns to those of other prehistoric material (1989) lends support to the suggestion that many 'stray' finds are probably from prehistoric settlement sites and associated areas of agricultural activity. However, there would also appear to be a pattern of deliberate deposition, seen particularly in the finds from funerary and other 'ceremonial' contexts, and 'hoards' or multiple finds of axes. Some river and bog finds may also represent deliberate deposits (Cooney 1989, r55).

River finds. The remarkable number of river finds is largely due to the major drainage operations of the last I 50 years (e.g. the Bann Drainage Scheme of the I 840 S and I $920 \mathrm{~s} / 3$ os, the Lough Neagh Drainage Scheme of 
Number of axes per 100 square kilometre block (based on the Insh National Grid):-

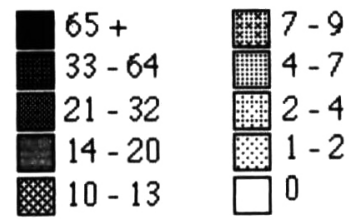

\section{.}

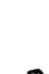

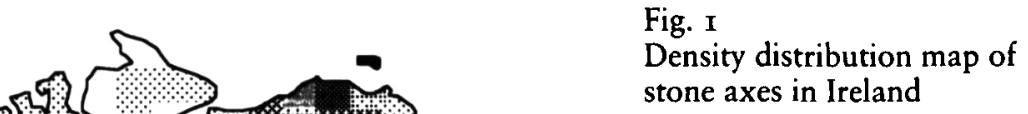




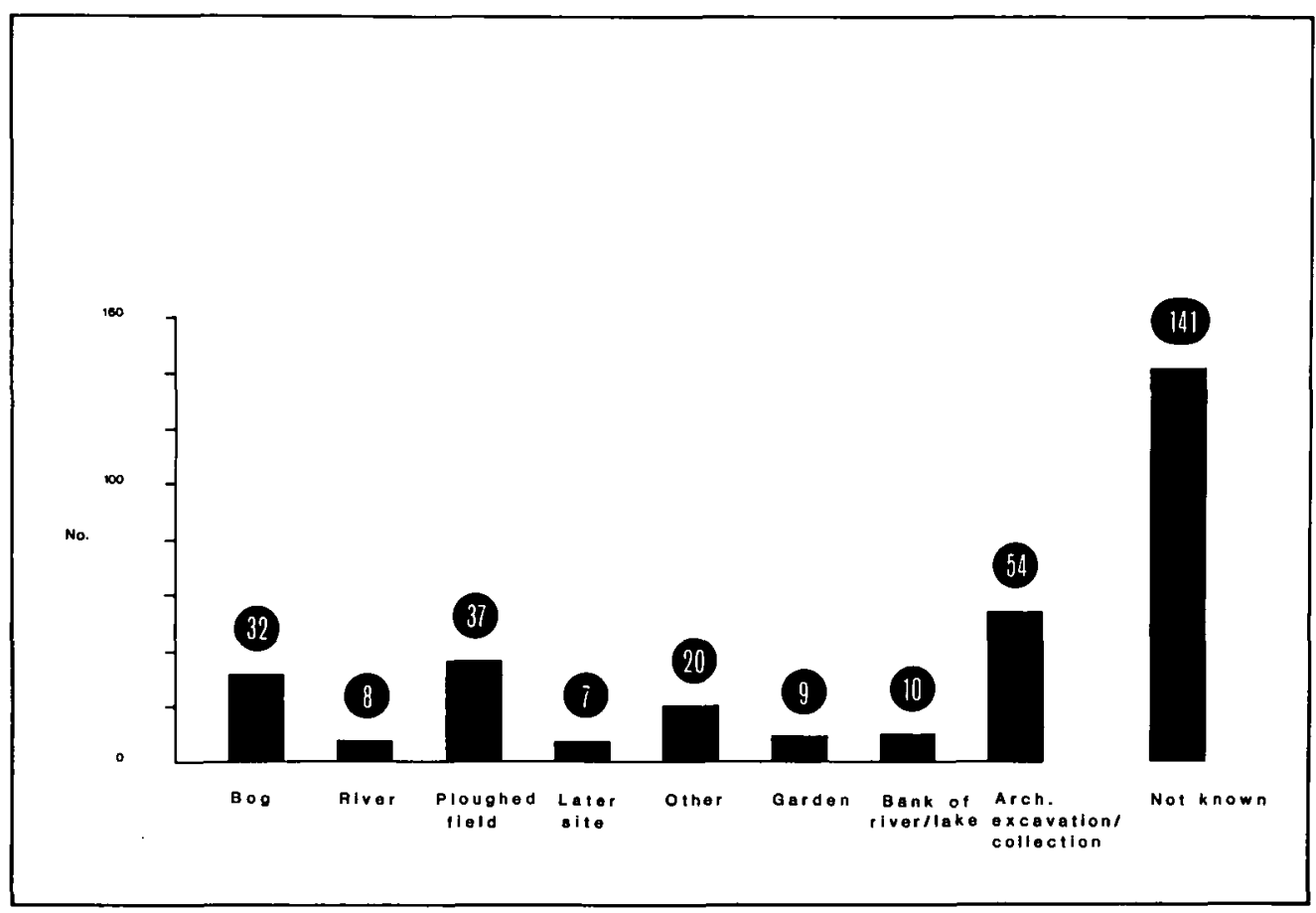

Fig. 2

Contexts of stone axes from north Leinster

of axes in Irish rivers. Deliberate deposition was involved in at least some cases - a pattern which continued with the deposition of fine metalwork in later prehistory (e.g. Bradley i 990a). Accidental loss over a lengthy period could also account for the concentration of finds at fording points on rivers such as the Shannon and the Barrow. Similarly, where riverine finds are dispersed rather than concentrated, this could be viewed as the result of either losses from riverside settlements or formal deposition.

Bog finds. The occurrence of considerable numbers of axes in bogs (particularly raised bogs) is unlikely to be explicable in terms of casual loss: whilst caution must always be exercised in reconstructing the landscape at the time of deposition, a case for deliberate deposition of at least some axes in pre-existing bogs or wet areas can be made. Possible examples include the two axes found together in a bog at Muckagh, Co. Westmeath (Armstrong I 9I 8, 9I); a polished flint axe from Downs, Co. Westmeath, found $2.1 \mathrm{~m}$ below the surface of a bog; and an axe found in a bog at Painestown, Co. Meath, close to a spread of antlers (information on the last two items from the NMI archive; cf. lake finds such as the axes found in Lough Gur, described by Armstrong in 1918). The deliberate deposition of metal artefacts in bogs had been recognized as an important aspects of Irish Bronze Age activity (e.g. Eogan I 983). It seems clear that we should now recognize deliberate deposition as a practice which also occurred during the Neolithic.

Funerary and other 'ceremonial' contexts (see Appen$\operatorname{dix} \mathrm{I}$ ). Complete and fragmentary axes are known to have been associated with I I court tombs, two portal tombs and two to four passage tombs, occurring in miniature form at one of the court tombs and two of the passage tombs. (The miniatures from the Carrowkeel Cairn $G$ passage tomb are perforated pendants thought to be in the form of Breton 'haches à bouton': Herity I974.) The contrast in frequency and nature between axe finds from court and portal tombs on the one hand and from passage tombs on the other may echo other differences in funerary practice between these types of monument: whilst court and portal tomb users deposited utilitarian-type items as grave goods and forecourt oblations, passage tomb users deposited artefacts such as items of personal adornment, status symbols and 'ritual' items. (A similar use of miniature axes and axe pendants is noted from Breton passage tombs: Herity 1974.) However, the axes found in court and portal tomb contexts are not without significance over and above their symbolic role as tools for the afterlife, as their placement with respect to tomb and chamber entrances and tomb-sealing events suggests (see also Edmonds \& Thomas 1987). 


\section{0. $J$. A. Sheridan et al. STONE AXE STUdies IN IRELAND}

Complete and fragmentary axes have also been found as grave goods in Neolithic single burial contexts: a complete specimen was found in a Linkardstown Type Burial (a monument type reserved almost exclusively for adults, usually males, in the south of the island), and axe chips were found with a $4-5$ year old child at Lough Gur Site D, accompanied by a pot and some flint flakes.

There are a handful of definite and alleged examples of the use of stone axes as grave goods in Bronze Age contexts; the latest of these is from the ring cairn cremation cemetery at Carnkenny, Co. Tyrone, dated to I I30-850 cal BC (Lynn I974). As for other 'ceremonial' contexts, the evidence is equivocal: of the six axes at the complex of stone alignments, circles and cairns at Beaghmore, Co. Tyrone, the only one to come from a well-documented context was found in a cist in Cairn Cr (May 1953). A 'hoard' comprising an adze and ro flakes, all of flint, allegedly found at the mouth of a socket for one of the stones of the Great Circle surrounding the main passage tomb at Newgrange (Hartnett 1954), can perhaps be ascribed to the Early Bronze Age on current reckoning (Sweetman 1985). However, as discussed below, it is hard to prove whether this was a votive offering or cache.

'Hoards'. Armstrong's I 9 I 8 survey of associated axes refers to seven reasonably convincing and around a dozen alleged instances where two or more axes have been found together. Since then, several other alleged axe hoards have been found. However, Briggs, applying source criticism to the original find reports, has rightly counselled caution in accepting specific groups of Irish axes as hoards ( $1988, \mathrm{II})$, whilst others (e.g. Bradley r990a; Whittle 1988, I23-27) have debated the various meanings to be attributed to hoards.

While it is not intended to discuss the definition and meaning of axe hoards in detail here, it should be noted that Armstrong's survey suggested the existence of several types, namely caches, votive deposits and manufacturers' hoards.

As for the first two, there are several alleged hoards which appear to fall into these categories, although it is hard to demonstrate unequivocally which examples belong to which category. Best known of these is the set of I 8 axes and one chisel, all of porcellanite, from 'Danesfort', Malone Road, Belfast, found at various times between I 869 and I 9 I 8 (pl. 20a; see Briggs I988, I I for a suggestion that they could represent 'domestic rejects' as easily as a ritual deposit). These items (contra Briggs) are clearly non-utilitarian prestige goods: they are larger than average, have a much higher polish than most specimens, and show no signs of having been used for chopping or chiselling. The 'Danesfort' find can be compared with a smaller group comprising three highly polished and apparently unused 'felstone' axes found in a shallow bog at Canrower, Oughterard, Co. Galway. A further cache or possibly votive hoard, discovered in 1933, consists of two axes, a nodule, 39 flakes, a chopper and a saw, all of flint, found at the base of the socket for a forecourt orthostat at Ballyalton court tomb, Co. Down (E. E. Evans \& Davies x934; compare with the Newgrange 'hoard' mentioned above).

As for 'manufacturers' hoards' - a concept queried by Briggs (I988, II) - Armstrong cites Knowles' discoveries of a group of five roughout porcellanite axes at various stages of completion from Glenariff, Co. Antrim, and a group of six axes found close to a sandstone grinding block at Culbane, Co. Derry (pl. 2ob). Knowles' suggestion for the latter that 'the person who ground the implements had intended to return the next day ... but ... in the meantime a flood had occurred in the Bann River, which either took a long time in subsiding, or else covered the axes and slab with a deposit of mud so that the place could not again be found' (Armstrong I 9 I 8, 82) may sound far-fetched, but an interpretation which involves axe manufacture - whatever the reason for deposition - seems reasonable.

\section{Morphology}

Although several scholars have commented on specific aspects of the morphology of Irish stone axes, the only study to have discussed the full range of material in detail is Knowles' I 893 paper. In this he proposed a formal classification of axes, and discussed the distinctions between axeheads and other woodworking implements represented in his and other collections, namely adzes, chisels and gouges. Whilst some of his terminology is arguably obsolete, and whilst a new scheme may emerge with the systematic study of the material now available, nevertheless Knowles' study covered virtually all the morphological variability which can be seen in Irish collections today. His scheme was useful in highlighting not only functional variation but also chronological and stylistic variation. For example, the 'Larne Implements' and 'Kitchen Midden Implements' which he suspected to be of early date have now been shown to be Mesolithic (Woodman 1978). Leaving 

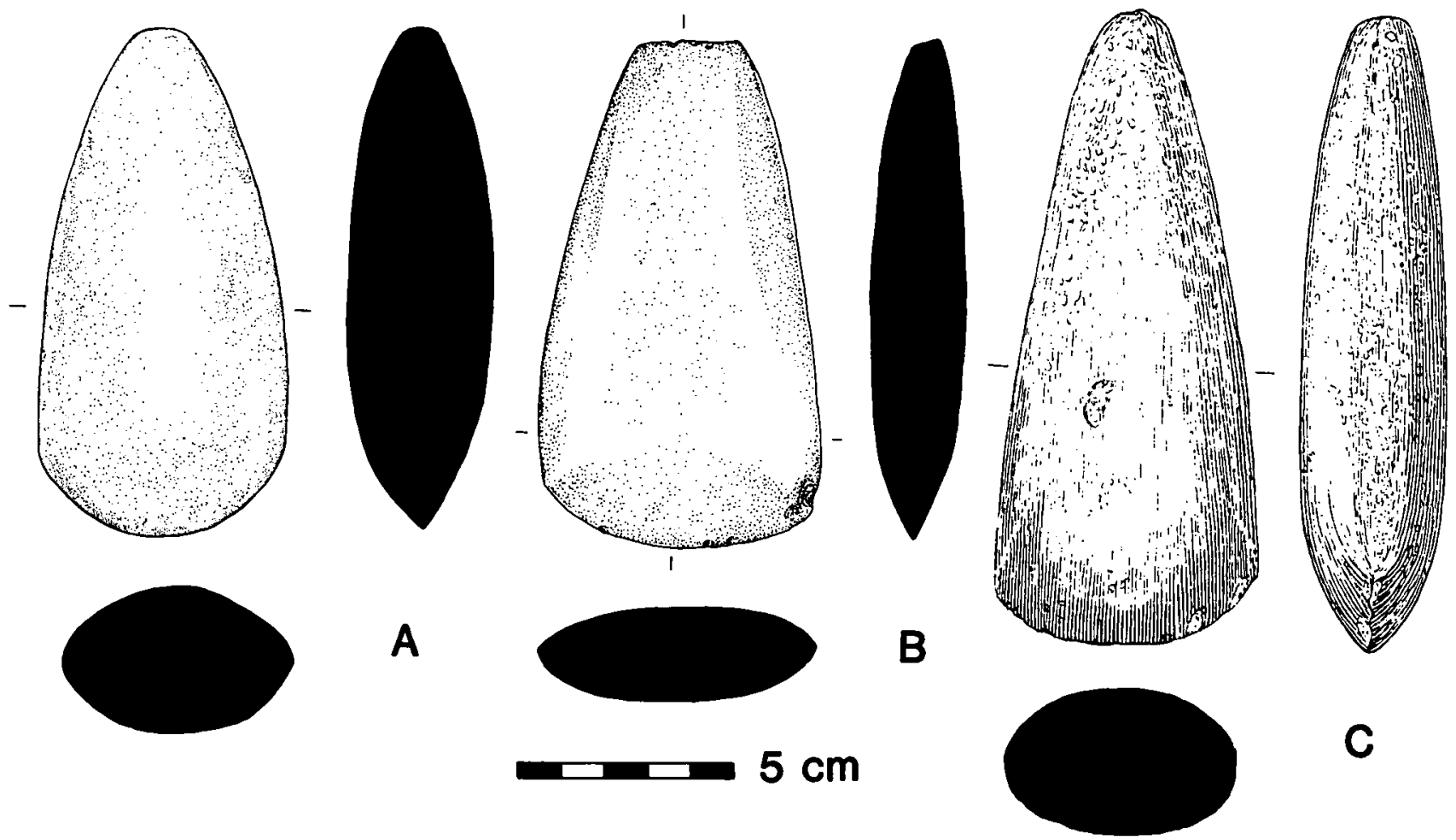

Fig. 3

Major morphological classes: (A) axe of symmetrical type, Co. Limerick (Dept. Arch., University College, Cork);

(B) axe with one convex and one straight side, Loughantarve, Co. Louth (County Louth Archaeological and

Historical Society Collection); (C) axe with straight, splaying sides, Mullacrew, Co. Louth (NMI)

these and the more unusual variants aside, the main types of axehead identified in this scheme are as follows (fig. 3):

Symmetrical (Knowles' 'ovate/subtriangular', 'stout ovate', 'broad ovate' and 'oval' forms, fig. 3 A). Symmetrical in outline, profile and section; sides and blade curved. Where blade curvature is gentle, the blade:side junction is sharp; where it is more marked, the blade merges with the sides.

Knowles' 'oblique-edged axes' (fig. $3 \mathrm{~B}$ ). One side straight, the other more or less convex; cutting edge asymmetrical in outline. See below (under 'Associated material') for further comments on such axes.

Splaying (fig. ${ }_{3} \mathrm{C}$ ). Straight-sided, splaying gently or more markedly towards the cutting edge.

These three main types vary in their butt shape, which can be rounded, pointed, flat or oblique. The sides can also vary in section from rounded to flattened or faceted.
Regarding stylistic variation, several of Knowles' observations merit further comment. Firstly, his recognition of a group of axes with squared sides, of fairly uniform shape (fig. 4 A; Knowles I 893, I 50 and fig. 3I), raises the question of whether deliberate copying of Group VI square-sided axes was taking place, as Jope later suggested of the porcellanite examples (I952,4I). It should be noted, however, that squared sides tend to be a feature of axes made of fine-grained sedimentary rocks such as mudstone, siltstone and ironstone (see also Chappell 1987 , figs 8.23, 9.12-13, 9.37-38). It may well be that the nature of the raw material was responsible in many cases for determining the shape.

Secondly, Knowles' observation that some highlypolished axes have a diagonal butt suggests that this feature may have been a deliberate design detail, associated with a class of 'prestige' specimens (fig. $4 \mathrm{~B}$ ). Sheridan (r986a) observed its presence on most of the items in the 'Danesfort' hoard, and also on several other highly polished unworn porcellanite implements, and noted that in some cases the butt facet had been 

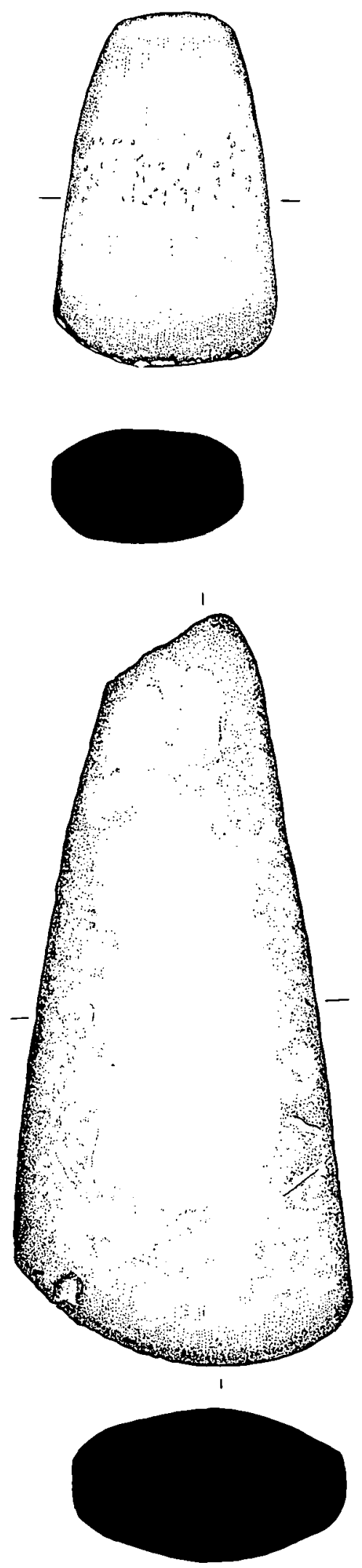

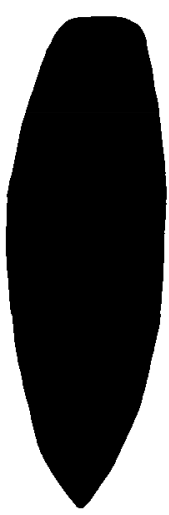

A

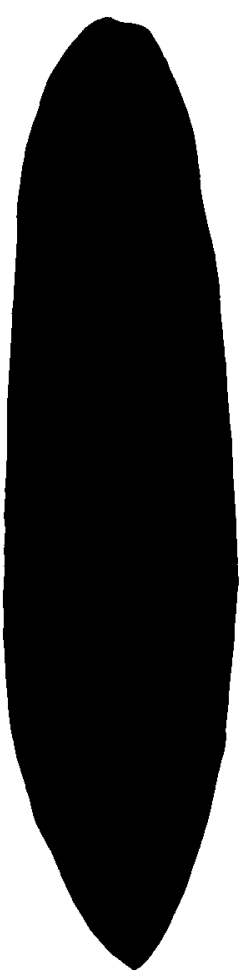

B
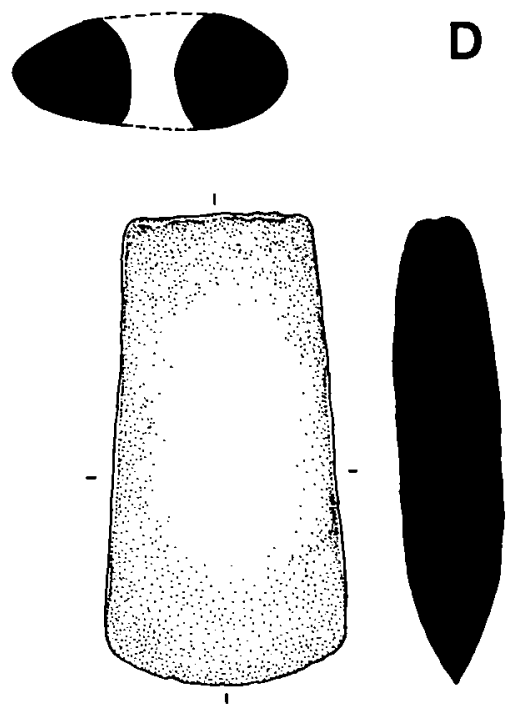

\section{$5 \mathrm{~cm}$}

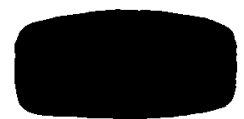

E

Fig. 4

Specific morphological classes: (A) axe with squared sides, Boyerstown, Co. Meath (NMI); (B) axe with diagonal butt, Ballynakill, Co. Meath (NMI); (C) miniature axe, Townleyhall, Co. Louth (NMI); (D) perforated axe, Ireland (Dept. Arch., University College, Dublin); (E) possible skeuomorph of metal axe, Dunbin, Co. Louth (County Louth Archaeological and Historical Society Collection) 
polished (a feature also observed by Knowles, I893, I 52 and Armstrong, I9I 8, 86). Knowles' comments make it clear that this feature was not limited to porcellanite items: a specimen from near Randalstown, Co. Antrim is of greenstone, for example. More work on the nature of obvious 'prestige' specimens is needed to ascertain the frequency of this oblique butt feature; other criteria which can be used to characterize 'prestige' specimens are the degree of polish, extraordinary size - though not an exclusive feature - and absence of evidence for utilitarian use (see Sheridan I 986 a for a discussion of the porcellanite specimens). However, when discussing the use of axes for 'social' purposes, it must be remembered that ethnographic cases exist where ordinary 'workaday' axes can perform this function as well as exclusively 'prestige' items.

Thirdly, Knowles' recognition of a group of miniature axes ( 1893 , I 53 and figs $4 \mathrm{I}-44$; fig. $4 \mathrm{C}$ ) raises the question of the function of such items. Sheridan has remarked $(1986 a, 23)$ that few of the porcellanite examples show any wear traces and has suggested that they may have been toys or amulets. However, Grogan (1989) has noted a tendency for small, worn axes (under $100 \mathrm{~mm}$ ) of other rock types to occur on settlement sites, such as Lough Gur, Co. Limerick. Such small axes could have been used for specialized woodworking tasks, perhaps hafted in a wooden or antler sleeve.

The use of some miniatures as amulets is suggested by the following examples: (a) a miniature axe in the passage tomb at Loughcrew (Cairn R2), Co. Meath and four pendants, possibly miniatures of Breton 'haches à bouton', in the passage tomb at Carrowkeel (Cairn G), Co. Sligo (Herity 1974) and (b) a miniature axe in the court tomb at Behy, Co. Mayo (de Valéra 1965). A further possible example is the miniature axehead found in association with fragments of what are probably polypod bowl legs, a piece of unburnt human skull, early Beaker pottery, a copper awl, a wristguard, scrapers and arrowheads in an occupation area associated with the construction of a cist cemetery at Cullen Longstone, Co. Tipperary (Danaher pers. comm.).

Fourthly, Knowles' observation ( I 893, I 57) that two of his axes had been perforated near their butt for suspension reminds one of Bradley's comments (I $990 \mathrm{~b}$ ) on the Later Neolithic re-use of axes as amulets or otherwise symbol-laden objects. Other examples include an axe perforated near the butt from Killaloe, Co. Clare, a centrally perforated axe from 'Ireland' in the teaching collection of the Department of Archaeo- logy, University College Dublin (fig. 4D), and one from Portrush, Co. Antrim, perforated near the cutting edge.

Fifthly, although not emphasized by Knowles, the fact that some axes appear to be skeuomorphs of Early Bronze Age flat metal axes (fig. ${ }_{4} \mathrm{E}$ ) has been noted by others such as Armstrong (I9 I 8). Similarly-shaped axes are known from Britain (e.g. some of the Cornish-origin 'Bridlington' axes of East Yorkshire and their counterparts in south-west England: Manby 1979, 68; and some of the Shetland Group XXII axes: Ritchie \& Scott I 988,88$)$. Whether or not they are skeuomorphs remains to be proven; the discovery of a splayed-blade (tranchet) axe in an Early Mesolithic context at $\mathrm{Nab}$ Head (David 1989) encourages caution with such an interpretation.

Finally, the large size of some 'prestige' axes, and the presence of miniature implements, has already been remarked upon. Regarding the broader mass of axes, recent studies by Grogan (1989) and Cooney (1989) of a sample of 443 complete axes from north Leinster and Munster have revealed that most $(65 \%)$ are between 90-160 $\mathrm{mm}$ long. This parallels the pattern noted by Darvill (r989) for Wales and the Mid-West of England.

\section{Associated material}

By this is meant axe hafts, grinding/polishing stones and containers, all of which are rare. The authors know of a mere five hafts, surviving in one form or another (fig. 5); all were bog finds, and all are in the NMI. Others are recorded but no longer extant (e.g. the partial haft with axehead from near Ballymena, Co. Antrim, mentioned by O'Laverty in 1857 ). All the extant specimens are single pieces of timber, into which the axeheads were inserted in a perforation at the thicker end. No examples of composite wooden or wood-and-antler hafts are known from Ireland, although axes of the appropriate size (including Mesolithic core axes) are known, with the surface of some examples apparently deliberately roughened in the butt area. The types of wood used were alder (Edercloon, Co. Longford, fig. $5 \mathrm{~A}$; Carrowntreila, Co. Mayo), 'apple' (Rosaceae) (Maguire's Bridge, Co. Fermanagh) and pine (Co. Monaghan, fig. 5B) (Coles et al. I978; H. S. Green 1978). The wood of the fifth haft, from Lissard, Co. Longford, has not been identified. It is unclear whether additional binding material such as resin, thongs or twine was used to secure the implements; ethnographic observations and experimental work suggests that these would not be necessary. Indications of the way in which the axe was secured in the handle can also be obtained from haft 
20. J. A. Sheridan et al. STONE AXE STUdies IN IRELAND
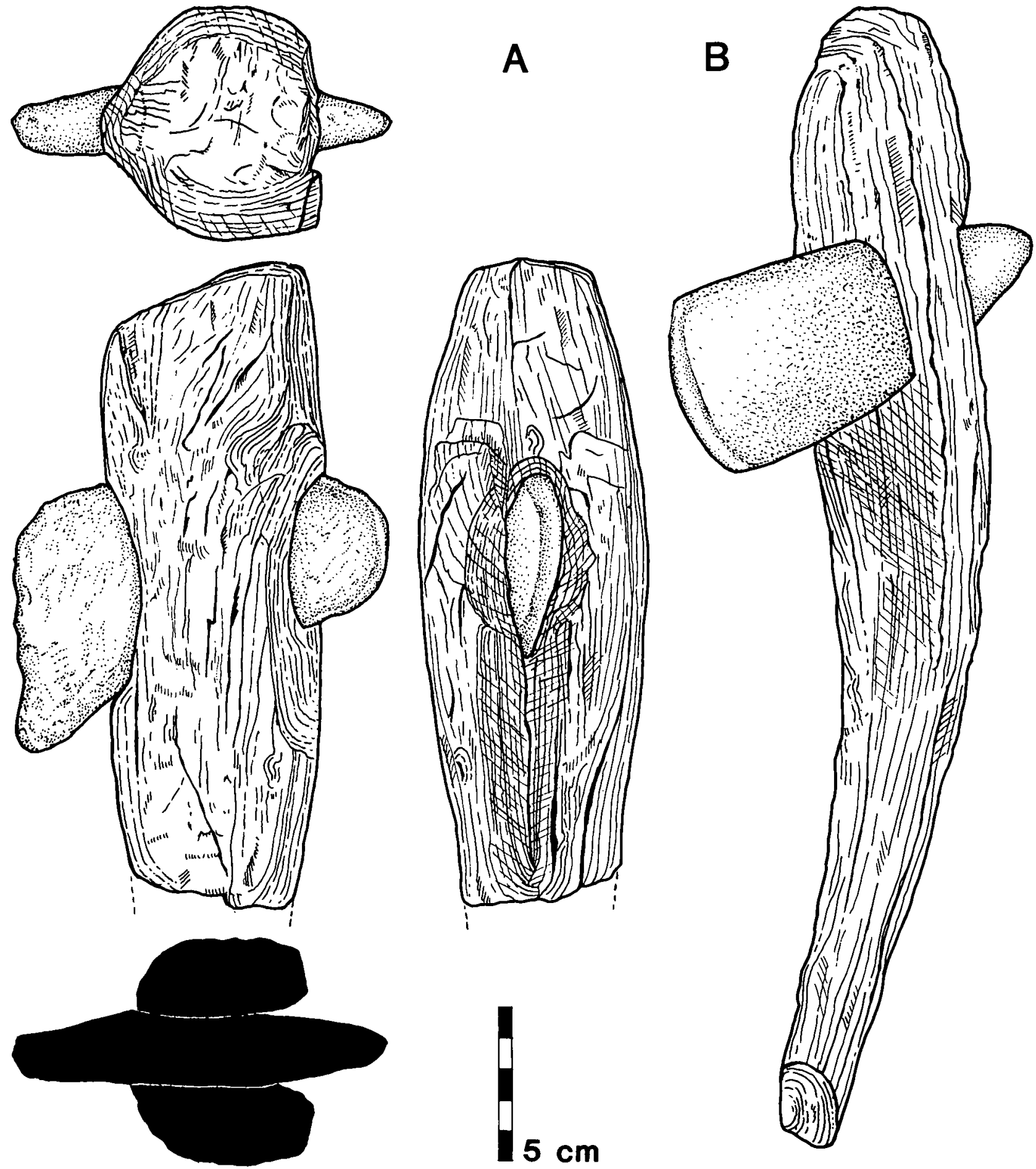

Fig. 5

Examples of axe hafts: (A) Edercloon, Co. Longford (NMI; J. Raftery I967, fig. I); (B) Co. Monaghan (NMI; after Wilde I 857) 
stains in some axes and the deliberate pecking of a band across the ground/polished surface on the upper part of the axe. While some axes (such as the one in the surviving handle from Co. Monaghan) appear to have been secured at roughly $90^{\circ}$ to the haft, others notably axeheads with lopsided blades - were hafted at a more acute angle, as appears to have been the case in the Edercloon example (fig. 5A). Semenov (I964, I 29-30) argued that this lopsidedness was the product of use rather than design, resulting from chopping wood with angled blows longitudinally along the surface.

A few portable sandstone grinding blocks are known from Irish museums (pl.2ob), although once more, other examples are known to have existed (Briggs 1988 , I I-I 2). Knowles, in discussing porcellanite axe manufacture around Tievebulliagh (I 903), suggested that the abundant outcrops of Old Red Sandstone in the nearby Glen Ballyemon could have been used as non-portable grinding stones, but added that no telltale hollows or striations had yet been spotted. He also reported possessing 2 I small rubbing stones which, he suggested, would have been used for polishing as well as the grinding blocks (1893, 1913).

One remarkable example of a stone axehead container is known from Aghintemple, Co. Longford. Here a circular or oval bag made of alder rods bound with strips of ligneous plant was found nearly $4 \mathrm{~m}$ deep in a bog, and in it was a small limestone axehead (J. Raftery I970).

Finally, although not strictly 'associated material', note should be made of the wood bearing axe or adze marks which has recently been found during excavations of Neolithic trackways at Corlea and Cloonbony, Co. Longford (B. Raftery I 990). The marks consist of short, rough facets which are clearly concave in section and profile with distinct ridges between adjoining facets.

\section{Dating}

As indicated above, a Mesolithic date for both flaked flint and ground stone axes in Ireland has now been established, with the earliest examples dating to the seventh millennium bc at Mount Sandel, Co. Derry (flint and stone) and Lough Boora, Co. Offaly (stone). The continuing use of both flint axes (albeit in largely different forms) and stone axes throughout the Neolithic period (c. $3800-2500 \mathrm{BC})$ is well attested, and it is clear that a wide range of forms and materials were in use from the Early Neolithic. As demonstrated above, there is evidence for the continuing use of stone axes throughout the Bronze Age (c. $2500-600 \mathrm{BC}$ ). Stone axes occur with surprising frequency on Early Christian and medieval sites as well, and while some of these are likely to be residual finds from earlier occupation, others were probably collected as curios or whetstones. (The collection of axes for similar reasons is also recorded from the more recent past, and continues still.)

The question of when stone axe production ceased is hard to resolve, particularly as several of the Bronze Age specimens come from funerary contexts where a 'special use of residual material' argument has been adduced by some (e.g. Lynn 1974). Porcellanite axes have, however, been found in Cordoned Urn domestic contexts at Downpatrick Meadowlands and Sheepland, both Co. Down (Pollock \& Waterman 1964; Waterman I 975); and if one accepts that these are not necessarily residual items, then their presence could be interpreted as the continuing use of a traditional, relatively abundant resource where alternative metal axes were scarce.

\section{Raw material exploitation}

Although the exploitation of raw material for axe manufacture has not yet been studied systematically in Ireland, preliminary studies by Cooney (1985; 1989), Grogan (r989) and Sheridan (I985) have shown that a wide variety of rock types was exploited, and have suggested extensive use of locally-available material. Some degree of ad hoc exploitation of whatever suitable material came to hand is suggested by the variety of resources used, from river-rounded cobbles to glacial erratics and dyke material; these vary widely in their hardness and working properties. Examination of assemblages of axes from excavated sites suggests, however, that some degree of selection was also practised, with the exploitation of preferred local rock types and sources and, in some cases, use of exotic material (see below). This appears to be the case at the hilltop Neolithic occupation site at Feltrim Hill, Co. Dublin, where in addition to a variety of material obtained from within $6 \mathrm{~km}$ of the site and a small amount of imported porcellanite, the inhabitants had made preferential use of the porphyritic andesite available from Lambay Island and Portrane, some I I km and $7 \mathrm{~km}$ distant respectively (Hartnett \& Eogan I964; J. Raftery 1968; 1969; I 971; 1973). The same is true for the Neolithic settlement complex at Lough Gur, Co. Limerick, where exploitation of nearby sources of sedimentary and igneous rocks has been suggested, in addition to use of 
glacial erratic material from the immediate vicinity of the sites and of imported porcellanite (Armstrong I918; S.P. Ó Ríordáin 1954; Grogan \& Eogan 1987; J. Raftery 1969).

Peter Woodman's research into Mesolithic resource use (r977a; 1978; 1985; I987; I989; Woodman \& Johnston in press) has revealed some points of similarity with the Neolithic pattern, with non-local preferred rock types being used (at least during the Later Mesolithic) as well as locally available material. The latter is represented by the pebble axes from Lough Boora, Co. Offaly and the chlorite schist axes from Newferry, Co. Antrim; the former by shale axes from Newferry (with a suggested source area to the west and south of Cookstown, Co. Tyrone, some $30 \mathrm{~km}$ distant), axes of good quality flint (from at least Io km away) from Bann Valley sites, and black mudstone axes from the Bann Valley (but see Briggs 1986; 1988). The raw material for the last-mentioned axes is suspected to originate in the Longford/Down Lower Palaeozoic peneplain, with the nearest possible sources lying at least $60 \mathrm{~km}$ away (Woodman \& Johnston in press). The extent to which the nature of Later Mesolithic 'exotic' rock exploitation resembles that during the Neolithic is, however, debatable. On the one hand, no axe manufacturing sites such as those associated with porcellanite exploitation (Briggs 1988; Knowles 1903; 1906; Sheridan 1986a) are known from Mesolithic Ireland. Furthermore a greater degree of mobility has been postulated for Mesolithic communities than for their Neolithic counterparts (Woodman I 978), thereby making it hard to distinguish between the movement of axes (or their raw materials) as a result of community moves, and axe movement by means of exchange between communities. On the other hand, the organization of axe production, the mechanisms of axe dispersal and the mobility of individuals and communities in Neolithic Ireland are not well understood, and it would be naive to adopt Houlder's (r976) model of axe producers, itinerant 'middlemen' and passive consumer communities uncritically (see Briggs 1988 and Sheridan I986a).

Many issues remain to be resolved in the study of raw material exploitation. Firstly, for example, Briggs has rightly argued (1977; I988) that more research is needed into the nature, distribution and use of naturally transported erratic rock, in order to distinguish locallyavailable from truly exotic material. Secondly, the list of the latter type of material (i.e. preferred non-local rock types) needs to be expanded in the light of current knowledge and the results of systematic study. Thirdly, more needs to be known about extraction and manufacturing sites (including those associated with porcellanite axes); and finally, the role of flint axes needs to be clarified.

Non-local preferred material. (I) Porcellanite. The widespread use of this material, both as a local resource (around the source areas) and as a non-local preferred rock type, procured either directly or indirectly, is well documented (e.g. Jope 1952; Sheridan 1986a; but see Briggs 1988). Over 125 porcellanite artefacts have come to light since publication of Sheridan's corpus in I986; these are listed in Appendix 2, and the updated distribution map is presented as fig. 6. Many of these specimens came to light as a result of Cooney's work on the NMI collections (particularly those of Co. Meath), and through Jon Marshall's fieldwalking and recording in north Antrim (Marshall I988). A high proportion come from areas outside the main concentration of porcellanite finds. The range of artefacts includes seven definite and possible Malone-type specimens, one chisel, four whetstone-like objects and a Largs-type macehead. The 'whetstones' and macehead join the already-documented spearhead and bracers (and more dubiously documented barbed and tanged arrowheads) in providing important clues about the timespan of porcellanite exploitation (see Sheridan I986a).

(2) Other Irish rock types (see below for flint). Several groups of axes sharing the same raw material have been identified, including the aforementioned black mudstone specimens which are concentrated in the Bann Valley (see Francis et al. I988 for details). However, Preston has wisely declined to attribute CBA IPC 'Group' labels to such groups on the grounds that either (a) specific source areas are as yet unknown; or (b) more than one source, or a single extensive source, of a particular rock type exists (Francis et al. 1988). Thus, for example, even though a coherent group of gabbroamphibolite-greenschist axes is identifiable and could derive from a single igneous rock mass, Francis et al. ( 1988 ) comment that these are common rock types in Lower Palaeozoic/Dalradian terrain, and that more than one source may have been used. That other similar axe groups will be discovered as a result of Cooney and Grogan's current research is virtually certain: Preston's work (not intended as a systematic study) had dealt with but a small percentage (c. $4 \%$ ) of the $10,600+$ axes known to exist in Ireland, and all of his specimens were from Ulster or 'Ireland'. 


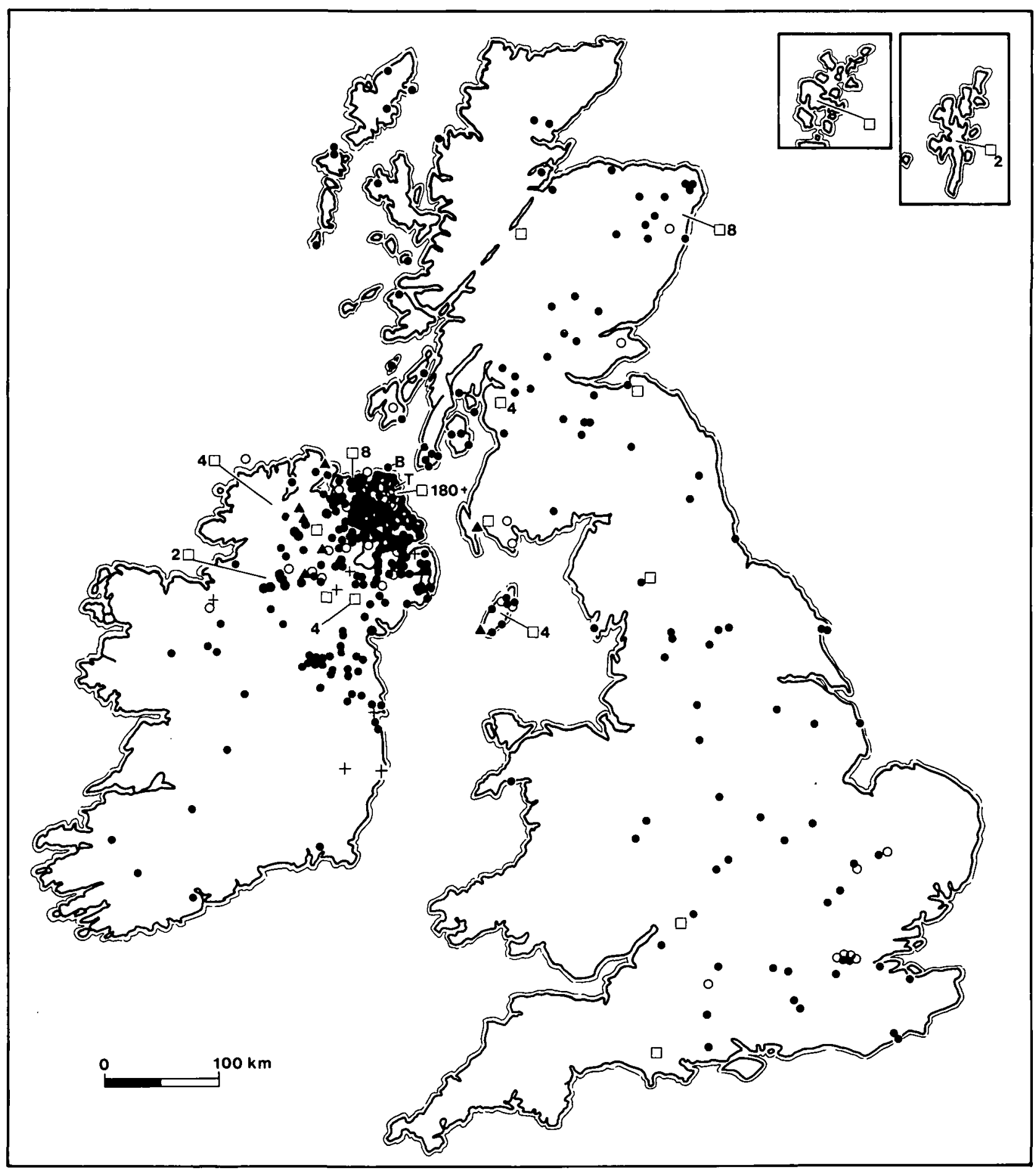

Fig. 6

Distribution map of porcellanite objects. Key: B = source at Brockley, Rathlin Island, Co. Antrim; $\mathrm{T}=$ source at Tievebulliagh, Co. Antrim ; solid dot = definite identification and findspot (to townland or equivalent level); open circle $=$ definite identification, findspot locality uncertain; open square $=$ definite or possible identification, provenanced to county only (numbers indicate multiple examples); solid triangle = possible identification, definite findspor; cross = definite or possible identification, findspot obviously not original (e.g. loft) 


\section{J. A. Sheridan et al. STONE AXE STUdies IN IRELAND}

(3) Imports to Ireland. The 19 currently-known definite and probable imports (all axes and all, apparently, of Neolithic date) are listed in Appendix 3; of these, ro are certainly or probably of Lake District origin, two are Group XIII axes from south-west Wales, and three are jadeite axes of probable Alpine (Piedmont) origin (Ricq-de Bouard pers. comm.). As for the Lake District specimens, their distribution in the North-East is interesting in the light of Burl's observation that the 'anomalous' megalithic monument at Ballynoe, Co. Down, is best understood as an outlier of his 'Cumbrian' stone circles of presumed Late Neolithic date (Burl 1976; Groenman-van Waateringe \& Butler 1976; see also Bradley \& Edmonds 1988). The presence of Group IX axes in north-west England provides further evidence for links between these two areas.

The remaining four axes are of considerable interest. Two, from rabbit warren upcast material at Doonooney, Co. Wexford (Corcoran I 966), are of unmistakably Scandinavian type, with parallels there dating to the Later Middle Neolithic, around 2900 BC (Becker 1973; Tauber 1972). Other Scandinavian axes (and a chisel), mostly of flint, are known from England and Wales, with an apparent concentration in the River Thames and on the Kent coast, yet the mechanisms of and reasons for their transmission to Britain and Ireland remain unclear (see Anderson 1984 for a summary and discussion of the British evidence). The other two are plump, square-sided polished flint axes from Co. Fermanagh (Jope \& Preston I953, fig. I), and from Drumraighland, Co. Derry (Woodman I992). These are comparable to C. N. Moore's 'Class 6' flint axes, which are common in the east and south of England and may be of mined flint (C. N. Moore I979; see also Whittle r977, 65).

Finally, there remain to be considered one axe and four pendant miniature axes which, although not known to be imported, nevertheless suggest that their users were familiar with types in use outside Ireland. These are the alleged Breton-type 'hache à bouton' from Derryhoosh, Co. Monaghan and the four miniature phallic 'hache à bouton' pendants from the passage tomb at Carrowkeel Cairn G, Co. Sligo (Herity r974, fig. 95). Full-sized 'haches à bouton' and miniature axes occur as grave goods in Breton passage tombs. This may add to the body of evidence suggesting links between Irish passage tomb users and their Breton (particularly Morbihanais) counterparts (O'Sullivan I986; Sheridan r986b).
Extraction and manufacturing sites. The nature of porcellanite exploitation has already been discussed in some detail by Jope (I952), Sheridan (1986a) and Briggs ( 1988 ); the present authors would concur with the view that porcellanite extraction involved the use of erratic material as well as outcrop rock (Sheridan I 986a, 27-28 and Briggs I988), and that the finishing of roughouts probably took place over a wide area, in domestic as well as 'special-purpose' contexts, up to a considerable distance from the source areas (see Sheridan I 986a, 22-23). As for flint, whose exploitation for axe manufacture has clearly been demonstrated in Co. Antrim (e.g. Collins 1978; Woodman 1992), the authors feel that the long-standing debate over the 'domestic' vs. 'industrial' nature of flint-extraction sites in general (Bennett \& Bell 1923; Briggs 1986; 1988; Case 1973; Collins 1978; E. E. Evans 1938b; I944; Whelan 1938) is fairly unproductive, since the multifaceted nature of many such sites has already been shown elsewhere (e.g. Flamborough Head: Manby I 974, 70-76; and the south English downland: Gardiner $1984,26-32$; 1990 ).

Extraction sites relating to other rock types are few, problematic, and little-studied. As noted above, there may be extraction sites of porphyritic andesite at Portrane and/or on Lambay Island, Co. Dublin, but the coarse-grained nature of this rock renders the identifcation of working sites extremely difficult. Systematic fieldwalking as part of the Ballylough Project has led to the identification of a rhyolite quarry to the north of Tramore, Co. Waterford (S.W. Green \& Zvelebil I990): whilst it is known that this source was used for tools during the Later Mesolithic and Neolithic, it is not clear whether it was used for axe manufacture. Rhyolite sources at the western end of the Dingle peninsula in Co. Kerry do, however, appear to have been exploited for this purpose, as indicated by the recovery of an unfinished rhyolite axe at Clogher Head (Woodman I989). M. C. Knowles (I904) referred to 'a place which had evidently been a manufactury of stone celts' at Fisherstreet, Co. Clare; but to the authors' knowledge, no work has subsequently been carried out to determine the nature and scale of axe manufacture at this site (W. J. Knowles 1902; Mahr 1937, 300-301).

Flint. (See also Woodman I992.) As in Britain (Darvill r989), flint axes have tended to be overlooked in most Irish axe studies. This is surprising in view of the abundance of flint deposits in Counties Antrim and Derry and the long-held and enduring interest in 


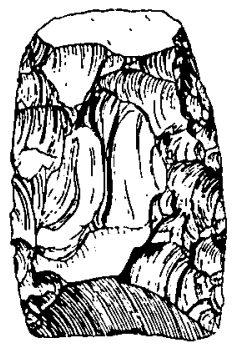

A

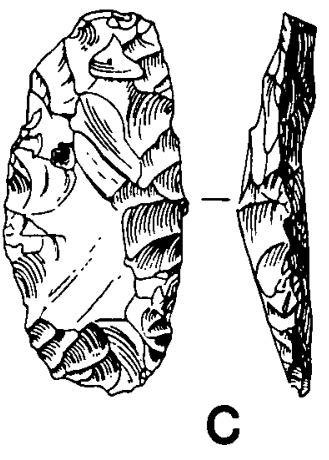

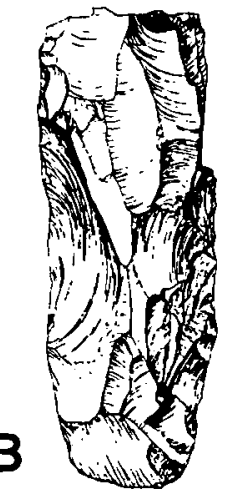

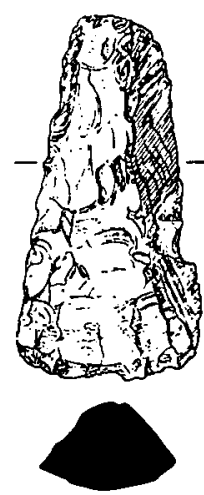

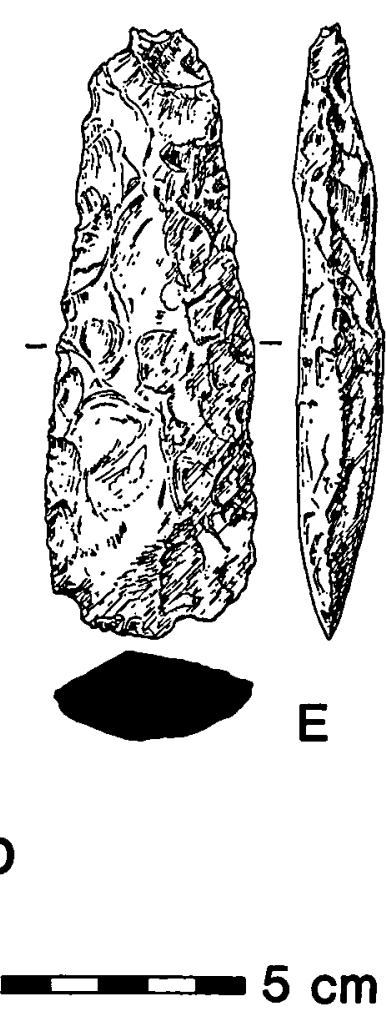
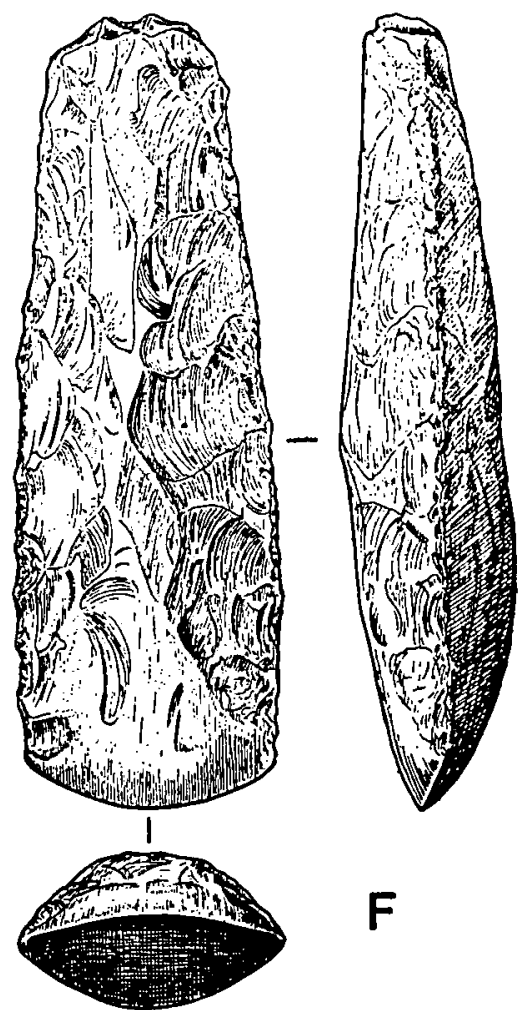

Fig. 7

Flint axe types: (A) Mesolithic flake axe, Mount Sandel, Co. Derry (UM; Woodman 1985, fig. 25); (B) Mesolithic core axe, Mount Sandel, Co. Derry (UM; Woodman I 985, fig. 24); (C) roughout Neolithic axe from Ballygalley Hill,

Co. Antrim (UM; Collins I 978, fig. I I : 27); (D) axe with plano-convex section, Castlefarm, Co. Dublin (NMI;

J. Raftery 1970, fig. I :6 (I05)); (E) axe with lentoid section, Killerk, Co. Tipperary (NMI; J. Raftery I97 I, fig. 2:35); (F) axe with ellipsoid section, Killarida, Co. Kerry (NMI; J. Raftery I96I, fig. I I)

collecting flint artefacts in north-east Ireland (Woodman 1978). Equally surprising is the divergence of views concerning their abundance; whilst Estyn Evans (1975) and Woodman (1992), echoing earlier writers (e.g. Davidson I950; J. Evans 1897; Gray I882), remark on their scarcity, Jope (1952) and Francis et al. ( 1988 ) have suggested that they are numerous.

It does indeed appear that flint axes are far less numerous than one might expect from the abundance of the raw material. They tend, predictably, to be more numerous in the North-East, where the main flint sources exist. Outside this area the distribution is very sparse but widespread; a high proportion of these specimens (and notably those in north Leinster) have ground or polished blades and are likely to be Neolithic in date.

Among the possible reasons for the overall paucity of flint axes are the facts that (a) two abundant sources of alternative good-quality axe material (i.e. porcellanite) are present - and were utilized - in the same general areas as the flint sources, (b) flint axes tend to be more brittle than most of their stone counterparts, so that where alternative stone sources exist, these may be used in preference (see Olausson 1983 for further discussion), and (c) debitage from axe manufacture, and re-used flint axe fragments, can sometimes be hard to distinguish from non-axe flakes or debitage). Woodman's re-evaluation of several Antrim flint assemblages (I992) provides useful evidence supporting points ' $a$ ' and ' $b$ '.

As mentioned above, the Mesolithic date of some Irish flint axes has been recognized for half a century (Movius 1942). The characteristics of these 'flake' and 'core' axes (fig. $7 \mathrm{~A}, \mathrm{~B}$ ), and their chronological distribution, have been discussed by Woodman (1978; 1985). Briefly, he argued that flake axes are characteristic of early Mesolithic industries, whilst core axes of various forms were in use - with some differences in sub-type - 


\section{J. A. Sheridan et al. STONE AXE STUdies In IRELAND}

throughout the period. (The term 'core axe' is used, widely yet somewhat confusingly, to refer to axes made from flakes whose cutting edge had been produced by secondary retouch: Woodman $1985,36$.

Mesolithic flake axes are clearly distinguishable from Neolithic flint axes on morphological and other grounds (see Woodman 1978 and 1985 for a detailed discussion). As far as core axes are concerned, however, there is some degree of morphological overlap between Mesolithic axes and Neolithic roughouts, as Woodman suggests (1985,36), and as is clearly shown by the Neolithic specimen from Ballygalley Hill, Co. Antrim (fig. 7 C; Collins 1978). Most Irish Neolithic flint axes are, nevertheless, clearly distinguishable from their Mesolithic predecessors, not least since most are manufactured from cores. Absent from the Mesolithic repertoire are the ovate specimens, such as are shown in fig. 7 D-F. These occur with profiles varying from the virtually plano-convex (fig. $7 \mathrm{D}$ ) to the lentoid (fig. $7 \mathrm{E}$ ) and roughly ellipsoid or rhomboid (fig. $7 \mathrm{~F}$ ).

The feature whhich most clearly distinguishes Neolithic flint axes from their earlier counterparts is the presence, on some specimens, of ground or polished surfaces. As Bell noted almost I 50 years ago, this tends to be restricted to the blade area; occasionally traces are found on raised surfaces further up the body of the axe. Flint axes with all-over polish are extremely rare in Ireland: in addition to the aforementioned probable imports found at Drumreaghland and in Co. Fermanagh, Knowles (I9I3, pl. XV, nos 70,7I) illustrated two specimens from the Bann Valley and commented on their scarcity. The reasons why flint axes were ground or polished in the blade area have been explored by Olausson, in her study of Scandinavian flint axes (x983). In her opinion, this treatment of the blade would serve to strengthen it and reduce friction on impact with wood. Its absence from other parts of the axe may be because it was both functionally unnecessary and time-consuming to effect. The presence of all-over polish on 'ceremonial' flint axes can thus be understood as one facet of the investment of time and skill in the manufacture of exclusively prestigious items.

As for post-Neolithic specimens, one possible candidate is the aforementioned (unpolished) adze from the socket of one of the stones surrounding the main Newgrange passage tomb (Hartnett 1954). Claims have been made for a Beaker date for the material near the entrance to this tomb, namely six axe fragments (some with ground surfaces) and three roughouts (O'Kelly I982, I88; O'Kelly et al. I983). However, an alternative interpretation for these objects as residual material from pre-tomb Neolithic occupation cannot be ruled out.

To what extent flint axes were exported from Ireland is currently unclear, since no systematic studies of flint axes in the north and west of Britain have been carried out. Nevertheless, one clear example of export to Scotland was discovered in December 1989 , in the form of a hoard of five axes and c. I 80 flakes of Antrim flint from Auchenhoan, near Campbeltown, Argyll (pl. 2. ; Saville \& Sheridan 1990). The axes comprise four lentoid and one roughly ellipsoid ovate specimens, all in pristine unused condition; one of the lentoid axes has traces of grinding around its blade and on a few high points higher up the body. All are closely comparable to specimens from Co. Antrim (cf. Woodman 1992).

Finally, the issue of whether any Irish flint sources outside the outcrop areas in Counties Antrim and Derry were used for axe manufacture has not yet been resolved, despite claims for the existence of such sources, and clear evidence for the widespread distribution of glacial erratic flint (Briggs I986; Woodman \& Griffiths 1988 ). One could argue that neither the axes nor the putative flint sources have yet been studied in sufficient detail to allow one to draw meaningful conclusions at this stage.

\section{CURRENT RESEARCH}

Clearly, a number of major areas of research need to be tackled if we wish to enhance our understanding of the production, use and meaning of stone axes and associated implements in earlier Irish prehistory. The most pressing need is for the creation of a reliable database on all such objects - not just those in the major collections but also those in private possession and in museums and collections outside Ireland. A systematic programme of raw material identification and sourcing is also essential, not least for establishing the extent of imports into Ireland and the scale of use of preferred sources. If linked with geological and field survey, such work should help with the identification of hitherto unrecognized sources and sites of extraction and axe production. Furthermore, in order to understand better the nature and organization of implement production and exchange, more detailed investigations at the extraction 
and production sites are needed (cf. Bradley \& Edmonds 1988; Edmonds et al. in press). Several specific issues relating to axe morphology and use need further attention, as indicated above; and in order to gain a deeper understanding of the economic, social and symbolic significance of axes, we need better information about their contexts of use and deposition. In other words, more research is needed into the true nature of 'stray' finds, the relationship between distribution patterns and the contemporary landscape, and the depositional patterning in various types of site.

With such issues in mind, the Irish Stone Axe Project has been initiated by two of the present authors (Cooney and Grogan), in collaboration with Chris Stillman of the Department of Geology, Trinity College, Dublin, with funding from the National Heritage Council. Its objective is to address the issues outlined above, principally through the establishment of a computerized database of all known stone axes in museum collections and private hands. This will provide information on the petrology, morphology, surface appearance, discovery date, context and history of each item .

The petrological work involves surface examination, followed by thin-section microscopic identification of a sample of $c .10 \%$ of the population, aimed at addressing specific problems such as the identification of groups of implements, imported specimens and likely sources. (This approach takes into account the fact that thin-section identification is not necessary in the case of some rock types, and not profitable in the case of others, such as many of the mudstones.) Other techniques such as trace element analysis will be used to address further specific problems, such as the separation of porcellanite axes from the Tievebulliagh and Rathlin sources.

The project is programmed to run for five years. On its completion, we should be in a position to present information on topics such as the relative scale of use of different rock sources, changing patterns of source use over time, patterns of axe deposition and discovery, and issues relating to morphology. The database will also facilitate other work, such as the systematic search for and investigation of production sites, use-wear analysis, and experimental work relating to morphology and function.

Acknowledgements. The authors express their grateful thanks to the following for advice and information: C. Bourke, R. Bradley, D. Clarke, P.Danaher, V.Davis, M. Edmonds, the late J.S. Jackson, S. McCartan, J. Mallory, J. Marshall, R. Ritchie, A. Saville, T.Skinner, J. Waddell, P. Woodman and M. Ryan and his staff in the National Museum of Ireland Antiquities Division.

\section{APPENDIX I: THE INCIDENCE OF AXES IN FUNERARY AND OTHER 'CEREMONIAL' CONTEXTS} IN NEOLITHIC AND BRONZE AGE IRELAND

NEOLITHIC CONTEXTS

Court tombs ${ }^{1}$

Ballymacaldrack, Co. Antrim

Ballymarlagh, Co. Antrim

Clontygora Large, Co. Armagh

Tamnyrankin east chamber,

Co. Derry

Ballyalton, Co. Down

Ballyglass, Co. Mayo (Megalithic

Survey no. Ma I 3 )

Ballyglass, Co. Mayo (Megalithic

Survey no. Ma I4)

Behy, Co. Mayo

Creevykeel, Co. Sligo
2 axes associated with tomb sealing; roughout outside cairn nr $\mathrm{S}$ horn; axe chip from surface at NW horn

2 axes in forecourt sealing deposits

Adze from Chamber I

Broken axe in middle of forecourt

2 axes from cache in socket of façade stone; axe in forecourt

Axe in front chamber of $W$ gallery

Axe from tomb

Miniature axe from chamber floor

Axe at $\mathrm{E}$ entrance to tomb; axe at boundary between $\mathrm{Ch}$ I and 2; axe chip from $\mathrm{Ch}_{2}$ floor; axe chip from court; chip against $S$ portal stone between Chs $\mathrm{I}$ and 2
E. E. Evans 1938a; Collins r976; Herity 1987

Davies 1949; Herity 1987 Davies \& Paterson 1937; Herity I987 Herring, unpublished notes

E. E. Evans \& Davies 1934; Herity 1987 de Valéra \& Ó Nualláin I 964 ; Ó Nualláin 1972a; 1976 de Valéra \& Ó Nualláin I 964; Ó Nualláin 1972 b; 1976 de Valéra I 965 ; de Valéra \& Ó Nualláin I 964 ; Ó Nualláin 1976

Hencken 1939; Herity 1987 (Herity claims that one of the chert items from the court is a flake axe) 
APPENDIX I: THE INCIDENCE OF AXES IN FUNERARY AND OTHER 'CEREMONIAL' CONTEXTS IN NEOLITHIC AND BRONZE AGE IRELAND Continued

Altanagh, Co. Tyrone

Portal tombs

Poulnabrone, Co. Clare

Dromanone, Co. Roscommon

Passage tombs ${ }^{2}$

Loughcrew Cairn R2, Co. Meath

Carrowkeel Cairn G, Co. Sligo

Linkardstown Type Burials

Linkardstown, Co. Carlow

Other individual Neolithic burials

Lough Gur Site D, Co. Limerick
Axe from area of presumed court tomb

chamber

Axe from chamber

Axe from chamber

Miniature axe from chamber

4 pendants resembling miniature Breton

'haches à bouton'

Axe from cist

Axe chips in burial of $4-5$ year old child

Axe from between gallery and kerb Axe from gallery

Axe in cist

Axe in cist

Chisel with Cordoned Urn in cist

Axe from Late Bronze Age ring cairn

6 axes from within and near cist in Cairn $\mathrm{C}_{I}$

Axe from ?unprotected cremation burial

Axe from cist
Williams 1986

Lynch $1986 ; 1988$

Topp 1962

Herity 1974

Herity 1974

J. Raftery 1944

S. P. Ó Ríordáin 1954
Herring \& May I 940

S. P. Ó Ríordáin \& Ó h-Iceadha I955

A. B. Ó Riordáin \& Waddell in press; Wakeman 1882

A. B. Ó Ríordáin \& Waddell in press; Simpson I 968 ; Wilde 1857

Cooney 1985 (with full

bibliography); Kavanagh 1976

Lynn 1974

May 1953

Plunkett \& Coffey I 898

Waddell, pers. comm.

1 A blade fragment from a polished mudstone axe was found at the base of the cairn, south of Chamber 2, at Bavan, Co. Donegal (Flanagan \& Flanagan 1966); its presence here suggests that it was not connected with the main use of the tomb.

2.1 Herity (I 974, I 75, I 79 and fig. I 20) discussed a set of objects in the NMI, including a broken polished flint axe, a fragment of another, two flint flake axes and a polished axe of black igneous rock, which were allegedly 'from the cairns at Loughcrew'. Woodman expressed serious doubts about the provenance of this material in $1977(1977 \mathrm{~b}, 26)$, but has nevertheless included one of the flint axes (NMI $194 \mathrm{I}-1427$ ) in his catalogue published in the present volume. Grogan and Cooney, having researched the NMI archive, are satisfied that both this specimen and the other fragmentary polished flint axe (NMI I $94 \mathrm{I}-\mathrm{I}_{42} \mathrm{I}$ ) did come from Loughcrew, although the recorded provenances are no more specific than 'cairn' and 'tomb' respectively.

2.2 An axe was found amongst 'domestic' material in the mound of the anomalous but passage tomb-related funerary site at Fourknocks 2, Co. Meath (Hartnett $197 \mathrm{I}$ ). Its presence might thus be due to the incorporation of pre-tomb habitation or feasting material.

${ }^{2.3}$ Six fragments of flint axes (both polished and unpolished), together with three 'roughout' flint axes and an unpolished flint adze (the last-mentioned being part of a cache of flints), were found near the entrance of the main passage tomb at Newgrange, Co. Meath (Hartnett I 954; O'Kelly I 982, I88; O'Kelly et al. 1983, 165). Their dating and interpretation remain uncertain.

${ }^{2.4}$ Herity (I 974) claims that other miniature axe pendants exist amongst the material from the passage tombs at Tara, Co. Meath and Carrowkeel Cairn K, Co. Sligo, and indeed further similar-shaped pendants are known from Loughcrew Cairns X and R2, Co. Meath (Herity I 974 , fig. 92). However, their interpretation as miniature axes is open to debate.

2-5 A fragment of a partly-polished flint axe was found in the cairn of the anomalous Neolithic tomb at Millin Bay, Co. Down (Collins \& Waterman 1955).

3.1 The authenticity of the association between the axe and the cist burial at Rathbarron was doubted by Armstrong (1918).

3.2 Simpson (1 968) illustrates a further supposed Food Vessel-axe association from Cookstown, Co. Tyrone, but it is clear from the original excavation report (E. E. Evans I944) that no axe was found. 
The information is presented in five columns, with keys as follows:

(I) Provenance. Exact findspot cited where possible; otherwise given as townland or equivalent. Suffix ' $t$ ' denotes where findspot is obviously secondary (e.g. loft).

(2) Irish/National Grid Reference or OS 6" sheet reference.

(3) Artefact type. $\mathrm{A}=$ axe (complete or fragment thereof); $\mathrm{AD}=$ adze; $\mathrm{CH}=$ chisel; $\mathrm{RO}=$ roughout for axe/adze/chisel; $\mathrm{F}=$ flake from polished axe/adze/chisel; $\mathrm{PP}=$ partly polished (roughout or flake); UF = unpolished flake from axe/adze/ chisel; $\quad \mathrm{UCH}=$ unpolished chip from axe/adze/chisel; $\mathrm{MAL}=$ Malone-type axe/adze/chisel; $\mathrm{WH}=$ whetstone; MACE $=$ macehead (Largs type).

(4) Current location. $\mathrm{ASNI}=$ Archaeological Survey of Northern Ireland; NMI = National Museum of Ireland; NMS = National Museums of Scotland; Private = in private collection; NTS = National Trust for Scotland; QUB = Queen's University of Belfast; UCD = University College Dublin; UM = Ulster Museum. Museum registration/record numbers included; $\mathrm{K}=$ Kevin collection, NMI.

(5) Mode of identification. XA = macroscopic, by archaeologist; XG = macroscopic, by geologist; * thin sectioned.

IRELAND

\begin{tabular}{|c|c|c|c|}
\hline Aghadrumglasny & 66 & $\mathrm{~A}$ & $\begin{array}{l}\text { Private } \\
\text { (UM RS I989.13a) }\end{array}$ \\
\hline Ballygalley ${ }^{1}$ & D 373405 & Several $A$ and $F$ & QUB \\
\hline Ballymacrea $\mathrm{Lr}$ & $2 / 6$ & A & Private \\
\hline Ballynagard & D I539 & UF & Private \\
\hline Ballyrock Scotch & C 925364 & A & Private \\
\hline Belfast, Balmoral Ave & J 3270 & A & $\begin{array}{l}\text { Private } \\
\text { (UM RS 1986.15) }\end{array}$ \\
\hline Belfast, off Antrim Rd & c. J 3377 & A & $\begin{array}{l}\text { Private } \\
\text { (UM RS I986.16) }\end{array}$ \\
\hline Black Mountain & c. J 2974 & A & UM A59.1986 \\
\hline Broughgammon & $\mathrm{DOSO} 4 \mathrm{I} 3$ & RO & Private \\
\hline Carnmoon & C 985374 & A & Private \\
\hline Carnsaggart & D 076423 & $5 \mathrm{~A}, \mathrm{RO}$ & Private \\
\hline Chatham & D 037328 & $2 \mathrm{~A}$ & Private \\
\hline Clegnagh & D 020355 & $3^{A}$ & Private \\
\hline Collin Mountain & c. $\mathrm{J} 2670$ & $A$ & $\begin{array}{l}\text { Private } \\
\text { (UM RS I986.13) }\end{array}$ \\
\hline Craigalappan & $D 025423$ & $3 \mathrm{~A}$ & Private \\
\hline Croaghbeg & D 007404 & $4 \mathrm{~A}$ & Private \\
\hline Between Dervock and Mosside & c. C 9933 & $\begin{array}{l}5 \mathrm{~A}, \mathrm{~A}(\mathrm{MAL}) \\
2 \mathrm{RO}, \mathrm{RO}(\mathrm{PP})\end{array}$ & Private \\
\hline Divis or Collin Mountain & c. $\mathrm{J} 2875$ or c. $\mathrm{J} 2670$ & A & $\begin{array}{l}\text { Private } \\
\text { (UM RS I988.2) }\end{array}$ \\
\hline Dooey & C 9442 & WH? & Private \\
\hline Drumnakeel & D I 60400 & $\mathrm{~F}(\mathrm{PP})$ & Private \\
\hline Gortconny & D 090429 & A & Private \\
\hline Island Carragh North & C 935360 & $5 \mathrm{~A}, \mathrm{WH}$ ? & Private \\
\hline Islandnanagh & D 058408 & $\mathrm{~A}$ & Private \\
\hline Knocknagarvan & D 036415 & IIA & Private \\
\hline Lagavara & D 043423 & A, UF & Private \\
\hline Loughlynch & C 995365 & RO & Private \\
\hline Maghernahar & $\mathrm{DO} 48408$ & A & Private \\
\hline Manister & D 022354 & WH? & Private \\
\hline North Antrim & - & $2 \mathrm{~A}, \mathrm{RO}$ & Private \\
\hline \multirow[t]{2}{*}{ ?Co. Antrim } & - & A & $\begin{array}{l}\text { Private } \\
\text { (UM RS r989.23) }\end{array}$ \\
\hline & \multicolumn{2}{|c|}{ Co Cork } & \\
\hline Coolnahane $^{2}$ & 86 & MACE & Private \\
\hline
\end{tabular}


APPENDIX 2: LIST OF PORCELLANITE ARTEFACTS WHICH HAVE COME TO LIGHT SINCE I986 (OR WERE OMITTED FROM THE I 986 corpus) Continued

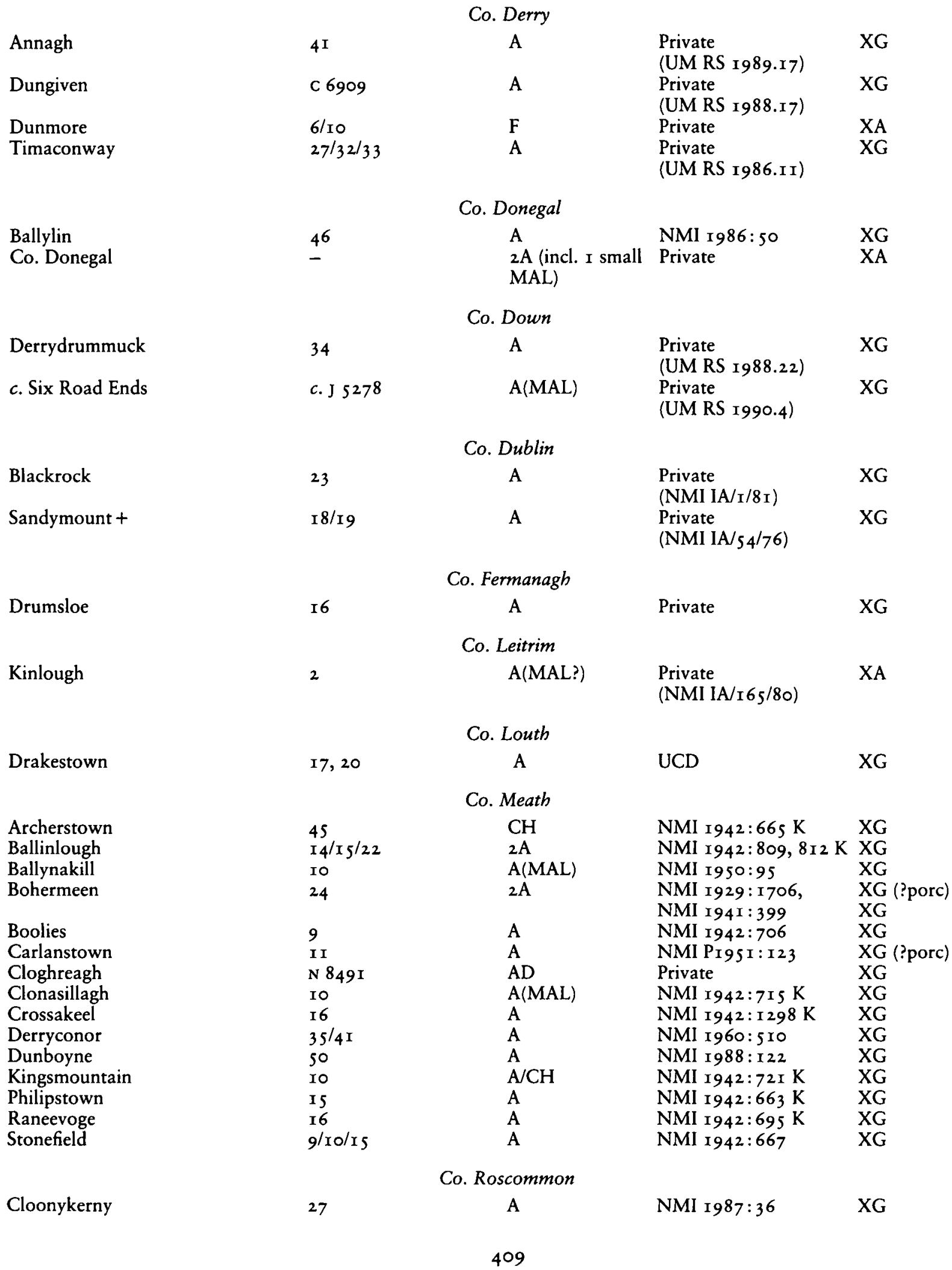


THE PREHISTORIC SOCIETY

APPENDIX 2: LIST OF PORCELLANITE ARTEFACTS WHICH HAVE COME TO LIGHT SINCE I986

(OR WERE OMITTED FROM THE I 986 corpus) Continued

\begin{tabular}{|c|c|c|c|c|}
\hline \multirow{3}{*}{ Ringroe $^{3}$} & \multicolumn{3}{|c|}{ Co. Tipperary } & \multirow[b]{2}{*}{$*$} \\
\hline & R 892900 & $\mathrm{~A}(\mathrm{MAL})$ & NMI I990:9 & \\
\hline & \multicolumn{3}{|c|}{ Co. Tyrone } & \\
\hline Altanagh 4 & H 623693 & A & ASNI & XG \\
\hline Ballylagan & 59 & A & $\begin{array}{l}\text { Private } \\
\text { (UM RS r989.16) }\end{array}$ & $X G$ \\
\hline \multirow[t]{2}{*}{ Pullateebee } & $5 / 6$ & A & $\begin{array}{l}\text { Private } \\
\text { (UM RS r989.I8) }\end{array}$ & XG \\
\hline & \multicolumn{3}{|c|}{ Co. Westmeath } & \\
\hline R. Shannon, Athlone & N 0394 I 5 & A & Not known & $X G$ \\
\hline \multicolumn{5}{|c|}{ Co. Wexford } \\
\hline \multicolumn{5}{|c|}{ Co. Wicklow } \\
\hline nr Brittas Bay + & 36 & A & $\begin{array}{l}\text { Private } \\
\text { (NMI IA/22/84) }\end{array}$ & XG \\
\hline \multicolumn{5}{|c|}{ No location, probably Northern Ireland } \\
\hline- & - & A & $\begin{array}{l}\text { Private } \\
\text { (UM RS I986.4) }\end{array}$ & $X G$ \\
\hline \multicolumn{5}{|c|}{$\begin{array}{l}\text { SCOTLAND } \\
\text { Aberdeenshire }\end{array}$} \\
\hline nr Kintore 5 & c. $\mathrm{NJ} 78 \mathrm{I} 6$ & A & NMS AF I05I & XA \\
\hline Prob. Aberdeenshire & - & A & NTS & XA \\
\hline \multicolumn{5}{|c|}{ Argyll } \\
\hline Machrins, Colonsay & NR 357928 & A & Cambridge U. & * \\
\hline \multicolumn{5}{|c|}{ East Lothian } \\
\hline Seton Mains, Longniddry & NT 4275 & A & Private & $\mathrm{XA}$ \\
\hline \multicolumn{5}{|c|}{ Inverness-shire } \\
\hline Allt Chrysal, Bentangaval, Barra ${ }^{7}$ & NL 6398 & $F$ & Sheffield U. & $\mathrm{XA}$ \\
\hline Boreray Is, N. Uist ${ }^{8}$ & c. NF $858 \mathrm{I}$ & A & NMS AF 1055 & $\mathrm{XA}$ \\
\hline \multicolumn{5}{|c|}{ Perthshire } \\
\hline Balnaguard $^{9}$ & NN 944518 & $\mathrm{AD}$ & NMS AF IIOI & $\mathrm{XA}$ \\
\hline \multicolumn{5}{|c|}{ Ross-shire } \\
\hline $\begin{array}{l}\text { Loch na Craoibhe, Kershader, } \\
\text { Lewis }\end{array}$ & NB $29 / 3018$ & A & NMS AF 965 & $\mathrm{XA}$ \\
\hline Cove, Loch Ewe & NG 8090 & A & NMS L.1958.1 6 & $\mathrm{XA}$ \\
\hline Shulishader, Lewis ${ }^{10}$ & NB 5334 & A & NMS AF 1097 & XA (prob porc) \\
\hline \multicolumn{5}{|c|}{ Shetland } \\
\hline Shetland ${ }^{11}$ & - & A & Shetland Mus & $\mathrm{XA}$ \\
\hline \multicolumn{5}{|c|}{ Sutherland } \\
\hline Cnoc ri Shaimhneig, Rogart & NC 7303 & A & $\begin{array}{l}\text { Dunrobin Castle Mus } \\
\text { I } 897.1\end{array}$ & XA \\
\hline \multicolumn{5}{|c|}{ Wigtownshire } \\
\hline nr Whithorn & c. NX 4440 & A & $\begin{array}{l}\text { Private } \\
\text { (NMS DB } 1987 / 12 \text { ) }\end{array}$ & $\mathrm{XA}$ \\
\hline
\end{tabular}

\footnotetext{
${ }^{1}$ From occupation site excavated by D. D. A. Simpson: Simpson et al. I 990; Simpson \& Conway, pers. comm. ${ }^{2}$ Simpson $1989 .{ }^{3}$ Cooney et al. 1990. ${ }^{4}$ Williams 1986. ${ }^{5}$ Proceedings of the Society of Antiquaries of Scotland 103 (1970-7 1), 242; CBA IPC no. ABN 124 . Appears in Sheridan 1986a as 'Aberdeenshire'. ${ }^{6}$ Mithen et al. 1987. 7 SEARCH I989. ${ }^{8}$ Proceedings of the Society of Antiquaries of Scotland ro5 (1 $972-74)$, 290. 9 Found amongst stones of North Mains-type cairn: Lawrie, pers. comm.; Mercer, pers. comm. ${ }^{10}$ Associated haft dated to $c$. 3495-29I0 cal BC (OxA-3537). ${ }^{11}$ Ritchie 1992.
} 
20. J. A. Sheridan et al. STONE AXE STUdies in IRELAND

APPENDIX 3: DETAILS OF IMPORTED AXES IN IRELAND

Key as Appendix 2.

\begin{tabular}{|c|c|c|c|c|}
\hline Findspot & Item & Material & Museum & Reference \\
\hline Portglenone, Co. Antrim & A & Gp VI & UM & $\begin{array}{l}\text { Clough \& Cummins } \\
\text { I } 988\end{array}$ \\
\hline Dundrum, Co. Down & A & Gp VI & UM & $\begin{array}{l}\text { Clough \& Cummins } \\
\text { 1988 }\end{array}$ \\
\hline Malone, Belfast, Co. Antrim & A & Gp VI & UM & $\begin{array}{l}\text { Clough \& Cummins } \\
\text { I988 }\end{array}$ \\
\hline Cushendall, Co. Antrim & A & Gp VI & UM & $\begin{array}{l}\text { Clough \& Cummins } \\
\text { I988 }\end{array}$ \\
\hline $\begin{array}{l}\text { Between Lisburn and Moira, Co. } \\
\text { Antrim }\end{array}$ & A & Gp VI & $\begin{array}{l}\text { Private (UM RS } \\
\text { 1971.1 I) }\end{array}$ & Unpublished \\
\hline Ballycoan, Co. Down & A & Gp VI (prob) & Private (UM RS I 977.7) & Unpublished \\
\hline Fergart, Co. Armagh ${ }^{1}$ & A & Gp VI (poss) & $\begin{array}{l}\text { Private (UM RS } \\
\text { I982.I2) }\end{array}$ & Unpublished \\
\hline Drumgooland, Co. Down & A & $\begin{array}{l}\text { Dacitic tuff, } \\
\text { Langdale }\end{array}$ & QUB & $\begin{array}{l}\text { Jope I966; Francis et al. } \\
\text { I } 988\end{array}$ \\
\hline Co. Antrim & A & $\begin{array}{l}\text { Gp VI? } \\
\text { (intermediate tuff) }\end{array}$ & Ashmolean & $\begin{array}{l}\text { Clough \& Cummins } \\
\text { I } 988 ; \text { Jope \& Preston }\end{array}$ \\
\hline Ireland & A & ?Gp VI & $\mathrm{UM}\left(\mathrm{A}_{3} 06.74\right)$ & $\begin{array}{l}\text { I953 } \\
\text { Unpublished }\end{array}$ \\
\hline $\begin{array}{l}\text { Carclinty (Carclunty) Bog, } \\
\text { Co. Antrim }\end{array}$ & A & Gp XIII & Avebury & $\begin{array}{l}\text { Keiller I936; Stone \& } \\
\text { Wallis I95 I (no. I } 7) ; \\
\text { Clough \& Cummins } \\
\text { I988 }(260, \text { no. I })^{2}\end{array}$ \\
\hline Co. Antrim & A & Gp XIII & Avebury & $\begin{array}{l}\text { Keiller I } 936 ; \text { Stone } 8 \\
\text { Wallis I } 95 \text { I (no. I } 8) \text {; } \\
\text { Clough \& Cummins } \\
\text { I } 988(260, \text { no. } 2)^{3}\end{array}$ \\
\hline Raymoghy, Co. Donegal & A & Jadeite & NMI & Smith $1963^{4}$ \\
\hline Nenagh, Co. Tipperary & A & Jadeite & NMI & Smith 1963 \\
\hline Paslickstown, Co. Westmeath & A & Jadeite & NMI & Smith 1963 \\
\hline Doonooney, Co. Wexford & A & $\begin{array}{l}\text { Green grit, } \\
\text { 'probably not of } \\
\text { Irish provenance' }\end{array}$ & NMI & Corcoran 1966 \\
\hline & $A^{5}$ & $\begin{array}{l}\text { Hard banded } \\
\text { stone }\end{array}$ & NMI & - \\
\hline Co. Fermanagh & A & Flint & Ashmolean & Jope \& Preston I953 \\
\hline Drumraighland, Co. Derry & A & Flint & NMI & Woodman I992 \\
\hline
\end{tabular}

\begin{abstract}
1 Jope (1966) refers to 'several' square-sided axes of possible Group VI rock in Co. Armagh, but does not list them. ${ }^{2}$ Keiller (1936) and Stone \& Wallis (195I) publish this as a Presely (Group XIII) stone axe, and Francis et al. (1988, I38) note Keiller's observations, but in the accompanying list (Clough \& Cummins 1988,260 ), the material is described simply as 'dolerite', rather than as 'Group XIII'. ${ }^{3}$ Comment as above, except that the material is here listed as 'greenstone'. ${ }^{4}$ See also Smith's comments on the axe from Tristia, Co. Mayo, which he regards as being of Galway ophicalcite, not jadeite $(1963,172) .{ }^{5}$ Corcoran's description of this thick-butted Lindø-type axe as an adze is incorrect.
\end{abstract}

\title{
ADDITIONAL NOTES
}

The flake from Lyles Hill, Co. Antrim, which Jope published as being from Graig Llwyd (Group VII), and which Preston subsequently identified in thin section as tuff resembling the Borrowdale Volcanics (E. E. Evans I953, 55 ; Jope \& Preston 1953, foornote 3), is reconsidered in Francis et al. 1988 , where judgment on its origin is reserved. The 'Graig Llwyd' flake from Squire's Hill (Jope I 952, 55) was re-identified by Preston in thin section as being of porcellanite (Jope \& Preston 1953 , footnote 3 ). A large, all-over-polished flint axe 'from the county Carlow', possibly of C.N. Moore's (1979) 'Class 7' type (and thus conceivably of Scandinavian origin: Sheridan 1992), was exhibited at the Royal Society of Antiquaries of Ireland in $189 \mathrm{I}$ (ffrench $\mathrm{I} 89 \mathrm{I}$ ). However, its probability of being an Irish find is open to doubt, as ffrench reported that he had obtained it from 'a house-painter long resident in Carlow' who had purchased it many years before. The axe is included in Woodman 1992. 


\section{BIBLIOGRAPHY}

Adkins, R. \& Jackson, R. 1978. Neolithic Stone and Flint Axes from the River Thames. London: British Museum.

Agrell, S. O. \& Langley, J. M. 1958. The dolerite plug at Tievebulliagh, near Cushendall, Co. Antrim. Proceedings of the Royal Irish Academy $59 \mathrm{~B}, 94-127$.

Anderson, J. B . 1984. Scandinavian Type Thick Butted Flint Axes in Britain: A Comparative Study. Unpublished M .A. Dissertation, Reading University.

Armstrong, E. C. R. I 9 I 8. Associated finds of Irish Neolithic celts. Proceedings of the Royal Irish Academy 34 C (1917I9), 8I-95.

Becker, C. J. I973. Studien zu neolithischen Flintbeilen. Acta Archaeologica 44, I 25-86.

Bennett, S. A. \& Bell, R. r923. A recently discovered prehistoric site in County Antrim. Proceedings of the Belfast Naturalists' Field Club 8 (r922-23), 242-55.

Bishop, A. C., Harrison, R. J., Kinnes, I. A. \& Woolley, A. R. 1977. Jadeite axes in Europe and the British Isles: an interim study. Archaeologia Atlantica 2, I-8.

Bonsall, C. (ed.) 1989. The Mesolithic in Europe: Papers Presented at the 3 rd International Symposium, Edinburgh 1985. Edinburgh: John Donald.

Bradley, R. J. I990a. The Passage of Arms. Cambridge: Cambridge University Press.

Bradley, R. J. I 9906 . Perforated stone axe-heads in the British Neolithic: their distribution and significance. Oxford Journal of Archaeology 9, 299-304.

Bradley, R. J. \& Edmonds, M. I988. Fieldwork at Great Langdale, Cumbria, 1985-1987: preliminary report. The Antiquaries Journal 68, 181-209.

Briggs, C. S. 1977. Stone axe 'trade' or glacial erratics? Current Archaeology 57, 303 .

Briggs, C. S. 1985. Some problems of survey and study in prehistoric Ireland: highland and lowland distributions in central Ulster, $c .3600-1800$ bc. In D. Spratt \& C. Burgess (eds), Upland Settlement in Britain, 35I-63. Oxford: British Archaeological Reports.

Briggs, C. S. 1986. Transported flint in Ireland: a charter of investigation for prehistory and geology. In G. de G. Sieveking \& M. B. Hart (eds), The Scientific Study of Flint and Chert, 18 5-90. Cambridge: Cambridge University Press.

Briggs, C. S. 1988. Stone resources and implements in prehistoric Ireland: a review. Ulster Journal of Archaeology 5 I, s-20.

Burl, A. 1976. The Stone Circles of the British Isles. New Haven: Yale University Press.

Case, H. J. 1973. A ritual site in north-east Ireland. In G. Daniel \& P. Kjaerum (eds), Megalithic Graves and Ritual, I73-96. Copenhagen: Jutland Archaeological Society.

Chappell, S. J. 1987. Stone Axe Morphology and Distribution in Neolithic Britain. Oxford: British Archaeological Reports.

Claris, P. \& Quartermaine, J. 1989. The Neolithic quarries and axe-factory sites of Great Langdale and Scafell Pike: a new field survey. Proceedings of the Prehistoric Society 55 , I-25.

Clarke, D. V. 1968. Two jadeite axes, and two arrowheads of Antrim porcellanite and Rhum bloodstone from Scotland.
Proceedings of the Society of Antiquaries of Scotland 100 (1967-68), I85-88.

Clough, T. H. McK. \& Cummins, W. A. r979. Stone Axe Studies. London: Council for British Archaeology.

Clough, T. H. McK. \& Cummins, W.A. 1988. Stone Axe Studies Volume 2. London: Council for British Archaeology.

Coles, J. M., Heal, S. V. E. \& Orme, B. J. 1978. The use and character of wood in prehistoric Britain and Ireland. Proceedings of the Prehistoric Society 44, I-45.

Collins, A. E. P. I976. Dooey's cairn, Ballymacaldrack, Co. Antrim. Ulster Journal of Archaeology 39, I-7.

Collins, A. E. P. 1978. Excavations on Ballygalley Hill, County Antrim. Ulster Journal of Archaeology 4I, I 5-32.

Collins, A. E. P. \& Waterman, D. 1955. Millin Bay: A Late Neolithic Cairn in County Down. Belfast: Her Majesty's Stationery Office.

Cooney, G. 1985 . Stone axes of County Louth: a first report. County Louth Archaeological and Historical Journal $2 \mathrm{I}$, 78-97.

Cooney, G. 1987. North Leinster in the Earlier Prehistoric Period. Unpublished Ph.D. thesis, National University of Ireland.

Cooney, G., 1989. Stone axes of North Leinster. Oxford Journal of Archaeology 8, 145-57.

Cooney, G., Feehan, J., Grogan, E. \& Stillman, C. 1990. An axe and an adze from Co. Tipperary with a preliminary list and distribution map of stone axes in Co. Tipperary. Tipperary Archaeological and Historical Journal 2, 197203.

Corcoran, J. X. W. P. 1966. An adze and an axehead from Co. Wexford. Journal of the Royal Society of Antiquaries of Ireland 96, 93-95.

Cummins, W. A. 1974. The Neolithic stone axe trade in Britain. Antiquity 48, 201-205.

Cummins, W. A. I 978 . Stone axe trade - or glacial erratics? Current Archaeology 61, 42-43.

Cummins, W. A. 1979. Neolithic stone axes: distribution and trade in England and Wales. In T. H. McK. Clough \& W. A. Cummins (eds), 5-I 2.

Cummins, W. A. I980. Stone axes as a guide to Neolithic communications and boundaries in England and Wales. Proceedings of the Prehistoric Society 46, 45-60.

Darvill, T. 1989. The circulation of Neolithic stone and flint axes: a case study from $W$ ales and the mid-west of England. Proceedings of the Prehistoric Society 55, 27-43.

David, A. 1989. Some aspects of the human presence in west Wales during the Mesolithic. In C. Bonsall (ed.), $24 \mathrm{I}-53$.

Davies, O. 1949. Excavations at the horned cairn of Ballymarlagh, Co. Antrim. Ulster Journal of Archaeology 12, 26-42.

Davies, O. \& Paterson, T. G. F. 1937. Excavations at Clontygora Large cairn, Co. Armagh. Proceedings of the Belfast Natural History and Philosophical Society 1936-37, $20-42$.

Dawson, J. I 95 I. The Brockley dolerite plug and the Church Bay volcanic vent, Rathlin Island, Co. Antrim. Irish Naturalists' Journal 10, 156-61.

de Valéra, R. 1965. Transeptal court cairns. Journal of the Royal Society of Antiquaries of Ireland 95, 5-37. 
de Valéra, R. \& O Nualláin, S. I964. Survey of the Megalithic Tombs of Ireland. Volume II: County Mayo. Dublin: Stationery Office.

Edmonds, M., Sheridan, J. A. \& Tipping, R. in press. Survey and excavation at Creag na Caillich, Killin, Perthshire. Proceedings of the Society of Antiquaries of Scotland $\mathbf{I 2 2}$.

Edmonds, M. \& Thomas, J. 1987. The Archers: an everyday story of country folk. In A. G. Brown \& M. Edmonds (eds), Lithic Analysis and Later British Prehistory, 187-99. Oxford: British Archaeological Reports.

Elliott, K., Ellman, D. \& Hodder, I. I978. The simulation of Neolithic axe dispersal in Britain. In I. Hodder (ed.), Simulation Studies in Archaeology, 79-87. Cambridge: Cambridge University Press.

Eogan, G. 1983. Hoards of the Later Bronze Age in Ireland. Dublin: University College, Dublin.

Evans, E. E. I938a. Doey's cairn, Dunloy, Co. Antrim. Ulster Journal of Archaeology I, 59-78.

Evans, E. E. I938b. Belfast, Co. Antrim. In Notes on excavations in Eire, England, Northern Ireland, Scotland and Wales during 1938. Proceedings of the Prehistoric Society I5, 322 .

Evans, E. E. I 944. Belfast: the site and the city. Ulster Journal of Archaeology 7, 5-29.

Evans, E. E. 1953. Lyles Hill. A Late Neolithic Site in County Antrim. Belfast: Her Majesty's Stationery Office.

Evans, E. E. 1975. An archaeological miscellany. Ulster Journal of Archaeology 38, I 2-I 8.

Evans, E. E. \& Davies, O. I934. Excavation of a chambered horned cairn at Ballyalton, Co. Down. Proceedings of the Belfast Natural History and Philosophical Society 193334, 79-104.

Evans, J. I897. The Ancient Stone Implements, Weapons and Ornaments of Great Britain. London: Longmans (2nd edn).

Evens, E. D., Grinsell, L. V., Piggott, S. \& Wallis, F. S. I962. Fourth report of the Sub-Committee of the South-Western Group of Museums and Art Galleries on the petrological identification of stone implements. Proceedings of the Prehistoric Society 28, 209-66.

ffrench, J. F. M. I 89r. A flint celt from the County Carlow and a stone celt from the County Kildare. Journal of the Royal Society of Antiquaries of Ireland 2I, 342-43.

Flanagan, L. N. W. \& Flanagan, D. I 966. The excavation of a court cairn at Bavan, Co. Donegal. Ulster Journal of Archaeology 29, 16-38.

Francis, E. L., Francis, P. J. \& Preston, J. I988. The petrological identification of stone implements from Ireland. In T. H. McK. Clough \& W. A. Cummins (eds), r 37-40.

Gardiner, J. I984. Lithic distributions and settlement patterns in central southern England. In R. J. Bradley \& J. Gardiner (eds), Neolithic Studies, I 5-40. Oxford: British Archaeological Reports.

Gardiner, J. I990. Flint procurement and Neolithic axe production on the South Downs: a re-assessment. Oxford Journal of Archaeology 9, I I 9-40.

Gray, W. I 882. The character and distribution of the rudelyworked flints of the north of Ireland, chiefly in Antrim and Down. Journal of the Royal Society of Antiquaries of Ireland 5 (1879-92), ro9-43.
Green, H. S. I978. Late Bronze Age wooden hafts from Llyn Fawr and Penywyllt, and a review of the evidence for the selection of wood for tool and weapon handles in Neolithic and Bronze Age Britain. Bulletin of the Board of Celtic Studies 28(I), I 36-4I.

Green, S. W. \& Zvelebil, M. I990. The Mesolithic colonization and agricultural transition of south-east Ireland. Proceedings of the Prehistoric Society 56, 57-88.

Groenman-van Waateringe, W. \& Butler, J.J. I976. The Ballynoe stone circle. Excavations by A.E. van Giffen I937-I938. Palaeohistoria I8, 73-I04.

Grogan, E. 1.989. The Early Prehistory of the Lough Gur Region: Neolithic and Early Bronze Age Settlement Patterns in North Munster South of the River Shannon. Unpublished Ph.D. thesis, National University of Ireland.

Grogan, E. \& Cooney, G. I 990 . A preliminary distribution map of stone axes in Ireland. Antiquity 64, 559-6I.

Grogan, E. \& Eogan, G. I 987 . Lough Gur excavations by Sean P. Ó Ríordáin: further Neolithic and Beaker habitations on Knockadoon. Proceedings of the Royal Irish Academy 87 C, 299-506.

Hartnett, P. J. I954. Newgrange passage grave, Co. Meath. Journal of the Royal Society of Antiquaries of Ireland $\mathbf{8 4}$, I 8 I-82.

Hartnett, P. J. I97I. The excavation of two tumuli at Fourknocks (sites 2 and 3), Co. Meath. Proceedings of the Royal Irish Academy 7 I C, 35-89.

Hartnett, P. J. \& Eogan, G. I964. Feltrim Hill, Co. Dublin: a Neolithic and Early Christian site. Journal of the Royal Society of Antiquaries of Ireland 94, I-38.

Hencken, H. O'N. 1939. A long cairn at Creevykeel, Co. Sligo. Journal of the Royal Society of Antiquaries of Ireland 49, 53-98.

Herity, M. I974. Irish Passage Graves. Dublin: Irish Universities Press.

Herity, M. I987. The finds from Irish court tombs. Proceedings of the Royal Irish Academy 87 C, I03-28I.

Herring, I. J. \& May, A. McL. 1940. Cloghnagalla cairn, Boviel, Co. Londonderry. Ulster Journal of Archaeology 3 , $4 I-55$.

Hodder, I. \& Lane, P. I982. A contextual examination of Neolithic axe distributions in Britain. In J.E. Ericson \& T.K. Earle (eds), Contexts for Prehistoric Exchange, 213-35. New York: Academic Press.

Houlder, C. I 976. Stone axes and henge monuments. In G. C. Boon \& J. M. Lewis (eds), Welsh Antiquity: Papers Presented to H.N. Savory, 55-62. Cardiff: National Museum of Wales.

Jope, E. M. I952. Porcellanite axes from factories in northeast Ireland: Tievebulliagh and Rathlin. Part I. Archaeological survey. Ulster Journal of Archaeology I 5, 3 I-55.

Jope, E. M. 1966. An Archaeological Survey of County Down. Belfast: Her Majesty's Stationery Office.

Jope, E. M. \& Preston, J. I953. An axe of stone from Great Langdale, Lake District, found in County Antrim. Ulster Journal of Archaeology 16, 3 I-36.

Kavanagh, R. I976. Collared and Cordoned Urns in Ireland. Proceedings of the Royal Irish Academy 76 C, 293-403.

Keiller, A. I936. Two axes of Presely stone from Ireland. Antiquity 10, 220-2I. 
Keiller, A., Piggott, S. \& Wallis, F.S. 194I. First report of the Sub-Committee of the South-Western Group of Museums and Art Galleries on the petrological identification of stone axes. Proceedings of the Prehistoric Society 7 , $50-72$.

Knowles, M. C. 1904. Kitchen middens - Co. Clare. Journal of the Limerick Field Club 2, 35-42.

Knowles, W. J. I893. Irish stone axes and chisels. Journal of the Royal Society of Antiquaries of Ireland 3 ( 5 th Series), I 40-63.

Knowles, W. J. 1902. The fourth report on the prehistoric remains from the sandhills of the coast of Ireland. Proceedings of the Royal Irish Academy 6 (1900-1902), $33 \mathrm{I}-89$.

Knowles, W. J. I903. Stone axe factories near Cushendall, Co. Antrim. Journal of the Royal Anthropological Institute 33, 360-66.

Knowles, W. J. I906. Stone axe factories near Cushendall. Journal of the Royal Society of Antiquaries of Ireland 36, 383-94.

Knowles, W. J. I9I3. Prehistoric stone implements from the River Bann and Lough Neagh. Proceedings of the Royal Irish Academy $30 \mathrm{C}$ (1912-I3), 195-222.

Livens, R. G. 1959. Petrology of Scottish stone implements. Proceedings of the Society of Antiquaries of Scotland 92 (I 958-59), 56-70.

Lynch, A. 1986. Poulnabrone. Excavations 1986, 12.

Lynch, A. I 988. Poulnabrone - a stone in time. Archaeology Ireland 2, 105-107.

Lynn, C. 1974. The excavation of a ring-cairn in Carnkenny townland, Co. Tyrone. Ulster Journal of Archaeology 36-37 (I973-74), I7-3 I.

McVicar, J. B. 1982. The spatial analysis of axe size and the Scottish axe distribution. Archaeological Reviews from Cambridge I(2), 30-45.

Mahr, G. 1 937. New aspects and problems in Irish prehistory: Presidential Address for 1937. Proceedings of the Prehistoric Society 3, 26I-436.

Mallory, J. 1985 . Ulster archaeology in 1984 . Ulster Journal of Archaeology 48, I-4.

Mallory, J. 1990. Trial excavations at Tievebulliagh, Co. Antrim. Ulster Journal of Archaeology 53, r 5-28.

Manby, T. 1974. Grooved Ware Sites in Yorkshire and the North of England. Oxford: British Archaeological Reports.

Manby, T. 1979. Typology, materials and distribution of flint and stone axes in Yorkshire. In T. H. McK. Clough \& W. A. Cummins (eds), 65-8 I.

Marshall, J. 9988 . Fieldwalking in North Antrim. Excavations $1988,4 \mathrm{I}-42$.

May, A. McL. I953. Neolithic habitation site, stone circles and alignments at Beaghmore, Co. Tyrone. Journal of the Royal Society of Antiquaries of Ireland 83, I 74-97.

Mithen, S. J., Reynolds, T. R. G. \& Chinner, G. A. I987. A porcellanite axe from Colonsay. Ulster Journal of Archaeo$\log y$ 50, I 59-60.

Moore, C. N. I 979 . Stone axes from the East Midlands. In T. H. McK. Clough \& W. A. Cummins (eds), 82-86.

Morey, J. E. \& Sabine, P. A. 1952. Porcellanite axes from factories in north-east Ireland: Tievebulliagh and Rathlin: Part II. A petrographical review of the porcellanite axes of north-east Ireland. Ulster Journal of Archaeology I5, 56-60.

Movius, H. L. 1942. The Irish Stone Age. Cambridge: Cambridge University Press.

O'Kelly, M. J. 1982. Newgrange: Archaeology, Art and Legend. London: Thames \& Hudson.

O'Kelly, M. J., Cleary, R. M. \& Lehane, D. (ed. C. O'Kelly) I.983. Newgrange, Co. Meath, Ireland. The Late Neolithicl Beaker Period Settlement. Oxford: British Archaeological Reports.

Olausson, D. 1983. Lithic Technological Analysis of the Thin-butted Axe. Lund: Bloms Boktryckeri.

O'Laverty, J. I857. Relative antiquity of stone and bronze weapons. Ulster Journal of Archaeology 5 (Ist series), I 22-27.

Ó Nualláin, S. I972a. A Neolithic house at Ballyglass near Ballycastle, County Mayo. Journal of the Royal Society of Antiquaries of Ireland 102, 49-57.

Ó Nualláin, S. 1 972 2b. Ballyglass. Excavations 1972, $20-22$.

Ó Nualláin, S. 1976. The central court-tombs of the northwest of Ireland. Journal of the Royal Society of Antiquaries of Ireland 106, 92-I 17.

Ó Ríordáin, A. B. \& Waddell, J. (eds) in press. The Funerary Bowls and Vases of the Irish Bronze Age. Galway: Galway University Press.

Ó Ríordáin, S. P. I 954. Lough Gur excavations: Neolithic and Bronze Age houses on Knockadoon. Proceedings of the Royal Irish Academy 56 C, 297-459.

Ó Ríordáin, S. P. \& O h-Iceadha, G. 1955. Lough Gur excavations: the megalithic tomb. Journal of the Royal Society of Antiquaries of Ireland 85,34-50.

O'Sullivan, M. 1986. Approaches to passage tomb art. Journal of the Royal Society of Antiquaries of Ireland $1 \mathrm{I6}$, 68-83.

Plunkett, T. \& Coffey, G. I 898. Report on the excavation of Topped Mountain cairn. Proceedings of the Royal Irish Academy 20 ( 3 rd ser, 4), $65 \mathrm{I}-58$.

Pollock, A. J. \& Waterman, D. 1964. A Bronze Age habitation site at Downpatrick. Ulster Journal of Archaeology 27, $3 I-58$.

Raftery, B. 1990. Trackways Through Time: Archaeological Investigations on Irish Bog Roads, 1985-1989. Dublin: Headline Publishing.

Raftery, J. 1944. A Neolithic burial in Co. Carlow. Journal of the Royal Society of Antiquaries of Ireland 74, 6I-62.

Raftery, J. I95 I. Prehistoric Ireland. London: Batsford.

Raftery, J. 1961. National Museum of Ireland: archaeological acquisitions for the year 1959. Journal of the Royal Society of Antiquaries of Ireland 91, 43-107.

Raftery, J. I967. National Museum of Ireland: archaeological acquisitions for the year 1964 . Journal of the Royal Society of Antiquaries of Ireland 97, $\mathrm{I}-28$.

Raftery, J. I 968. National Museum of Ireland: archaeological acquisitions for the year 1965. Journal of the Royal Society of Antiquaries of Ireland 98, 93-1 59.

Raftery, J. I 969 . National Museum of Ireland: archaeological acquisitions in the year 1966. Journal of the Royal Society of Antiquaries of Ireland 99, 93-I I 5.

Raftery, J. 1970 . Prehistoric coiled basketry bags. Journal of the Royal Society of Antiquaries of Ireland 100, I67-68. 
Raftery, J. I97I. National Museum of Ireland: archaeological acquisitions for the year 1968. Journal of the Royal Society of Antiquaries of Ireland I01, I 84-244.

Raftery, J. r973. National Museum of Ireland: archaeological acquisitions in the year 1970. Journal of the Royal Society of Antiquaries of Ireland $\mathrm{IO}_{3}, \mathrm{I}_{77-2} \mathrm{I} 3$.

Ritchie, P. R. 1968. The stone implement trade in thirdmillennium Scotland. In Coles, J. M. \& Simpson, D. D. A. (eds), Studies in Ancient Europe, I I 7-36. Leicester: Leicester University Press.

Ritchie, P. R. 1992. Stone axeheads and cushion maceheads from Orkney and Shetland: some similarities and contrasts. In N. M. Sharples \& J. A. Sheridan (eds), 21 3-20.

Ritchie, P. R. \& Scott, J. G. I 988 . The petrological identification of stone axes from Scotland. In T. H. McK. Clough \& W. A. Cummins (eds), 85-9I.

Ryan, M. 1980. An Early Mesolithic site in the Irish Midlands. Antiquity 54, 46-47.

Saville, A. \& Sheridan, J. A., I990. The Campbeltown flint hoard. Past $9,4$.

Scott, J. G. I969. The Clyde cairns of Scotland. In T. G. E. Powell, J. X. W. P. Corcoran, F. Lynch \& J. G. Scott (eds), Megalithic Enquiries in the West of Britain, 175-222. Liverpool: Liverpool University Press.

Scott, J. G. I 973 . Axeheads of Group IX from Kintyre, Argyll. Proceedings of the Prehistoric Society 39, 469-7I.

SEARCH r989. Sheffield Environment and Archaeology Campaign in the Hebrides. The Western Isles Project: 2 nd Interim Report. Sheffield: Sheffield University Department of Archaeology \& Prehistory.

Semenov, S. A. 1964. Prehistoric Technology. London: Cory, Adams \& MacKay.

Sharples, N. M. \& Sheridan, J. A. (eds), I 992 . Vessels for the Ancestors: Essays on the Neolithic of Britain and Ireland in Honour of Audrey Henshall. Edinburgh: Edinburgh University Press.

Sheridan, J. A. 1985. The Role of Exchange Studies in 'Social Archaeology', with Special Reference to the Prehistory of Ireland from the Fourth to the Early Second Millennium b.c. Unpublished Ph.D. thesis, Cambridge University.

Sheridan, J. A. 1986a. Porcellanite artefacts: a new survey. Ulster Journal of Archaeology 49, x9-32.

Sheridan, J. A. I986b. Megaliths and megalomania: an account and interpretation of the development of passage tombs in Ireland. The Journal of Irish Archaeology 3, I 7-30.

Sheridan, J. A. I992. Scottish stone axeheads: some new work and recent discoveries. In N. M. Sharples \& J. A. Sheridan (eds), 194-212.

Simpson, D. D. A. x968. Food Vessels: associations and chronology. In J.M. Coles \& D.D. A. Simpson (eds), Studies in Ancient Europe, 197-2 I I. Leicester: Leicester University Press.

Simpson, D. D. A. 1989. The stone maceheads of Ireland: Part II. Journal of the Royal Society of Antiquaries of Ireland I I9, I I 3-26.

Simpson, D. D. A., Conway, M. G. \& Moore, D. G. 1990. The Neolithic settlement at Ballygalley, Co. Antrim. Excavations 1989, interim report. Ulster Journal of Archaeology $53,40-49$.
Smith, W. C. 1963. Jade axes from sites in the British Isles. Proceedings of the Prehistoric Society 29, I 33-72.

Stone, J. F. S. \& Wallis, F. S. 1947. Second report of the Sub-Committee of the South-Western Group of Museums and Art Galleries on the petrological identification of stone axes. Proceedings of the Prehistoric Society 13, 47-55.

Stone, J. F. S. \& Wallis, F. S. I95I. Third report of the Sub-Committee of the South-Western Group of Museums and Art Galleries on the petrological identification of stone axes. Proceedings of the Prehistoric Society 17, 99-1 58.

Sweetman, P. D. 1985 . A Late Neolithic/Early Bronze Age pit circle at Newgrange, Co. Meath. Proceedings of the Royal Irish Academy 85 C, 195-221.

Tauber, H. 1972. Radiocarbon chronology of the Danish Mesolithic and Neolithic. Antiquity 46, 106-10.

Tomkeieff, S. I. I 940. The dolerite plugs of Tieveragh and Tievebulliagh, near Cushendall, Co. Antrim, with a note on Buchite. Geological Magazine 77, 54-64.

Topp, C. 1962. The portal dolmen of Dromanone, Roscommon. Bulletin of the Institute of Archaeology, University of London 3, 38-46.

Wakeman, W. F. 1882 . On some recent antiquarian discoveries at Toam and Killicarney, near Blacklion, in the County of Cavan. Journal of the Historical and Archaeological Association of Ireland 4 ser, 5 (1879-82), I93-200.

Waterman, D. 1975. A Bronze Age habitation site at Sheepland, Co. Down. Ulster Journal of Archaeology 38, 85-87.

Whelan, C. B . r934. Studies in the significance of the Irish stone age: the Campignian question. Proceedings of the Royal Irish Academy 42 C, I 2 I-43.

Whelan, C. B. 1938. Studies in the significance of the Irish Stone Age: the culture sequence. Proceedings of the Royal Irish Academy $44 \mathrm{C}$ ( $1937-38$ ), I I 5-37.

Whittle, A. W. R. 1977. The Earlier Neolithic of S. England and its Continental Background. Oxford: British Archaeological Reports.

Whittle, A. W. R. 1988. Problems in Neolithic Archaeology. Cambridge: Cambridge University Press.

Wilde, W. R. I 857. A Descriptive Catalogue of the Antiquities of Stone, Earthen and Vegetable Materials in the Museum of the Royal Irish Academy. Dublin: M. H. Gill.

Williams, B . B. I 986 . Excavations at Altanagh, Co. Tyrone. Ulster Journal of Archaeology 49, 33-88.

Woodman, P. C. I977a. Recent excavations at Newferry, Co. Antrim. Proceedings of the Prehistoric Society 43, $155^{-}$ 200.

Woodman, P. C. 1977b. Problems of identification of Mesolithic survivals in Ireland. Irish Archaeological Research Forum 4(2), 1 7-28.

Woodman, P. C. 1978. The Mesolithic in Ireland. Oxford: British Archaeological Reports.

Woodman, P. C. 1985. Excavations at Mount Sandel 1973-77. Belfast: Her Majesty's Stationery Office.

Woodman, P. C. 1987. The impact of resource availability on lithic industrial traditions in prehistoric Ireland. In P. Rowley-Conwy, M.Zvelebil \& H.P. Blankholm (eds), Mesolithic Northwest Europe: Recent Trends, I 38-46. Sheffield: Sheffield University Department of Archaeology \& Prehistory. 
Woodman, P. C. 1989. The Mesolithic of Munster: a preliminary assessment. In C. Bonsall (ed.), I I6-24.

Woodman, P. C. I992. Excavations at Mad Mans Window, Glenarm, Co. Antrim: problems of flint exploitation in east Antrim. Proceedings of the Prehistoric Society 58, 77-106. Woodman, P. C. \& Griffiths, D. A. I 988. The archaeological importance of flint sources in Munster. Journal of the Cork Historical and Archaeological Society 93, 66-72.
Woodman, P. C. \& Johnston, I. in press. A petrological examination of some Mesolithic stone artefacts. Ulster Journal of Archaeology.

Woolley, A. R., Bishop, A. C., Harrison, R. J. \& Kinnes, I. A. 1979. European Neolithic jade implements: a preliminary mineralogical and typological study. In T. H. McK. Clough \& W. A. Cummins (eds), 90-96. 